\title{
COMPARATIVE ASSESSMENT OF MODELS AND METHODS TO CALCULATE GRID ELECTRICITY EMISSIONS
}

\author{
by
}

Nicole A. Ryan

\author{
A thesis submitted \\ in partial fulfillment of the requirements \\ of the degree of \\ Master of Science \\ (Natural Resources and Environment) \\ in the University of Michigan \\ August 2016
}

Thesis Committee:

Professor Gregory A. Keoleian, Co-Chair

Assistant Professor Jeremiah X. Johnson Co-Chair 
This page intentionally left blank 


\begin{abstract}
Due to the complexity of power systems, tracking emissions attributable to a specific electrical load is a daunting challenge, but essential for many environmental impact studies. Currently, no consensus exists on appropriate methods for quantifying emissions from particular electricity loads. This thesis reviews a wide range of the existing methods, detailing their functionality, tractability, and appropriate use. We identified and reviewed 32 methods and models and classified them into two distinct categories: empirical data \& relationship models and power system optimization models. To illustrate the impact of method selection, we calculate the $\mathrm{CO}_{2}$ combustion emissions factors associated with electric vehicle charging using ten methods at nine charging station locations around the U.S. Across the methods, we found up to $68 \%$ difference from the mean $\mathrm{CO}_{2}$ emissions factor for a given charging site among both marginal and average emissions factors and up to a $63 \%$ difference from the average across average emissions factors. Our results underscore the importance of method selection and the need for a consensus on approaches appropriate for particular loads and research questions being addressed to achieve results that are more consistent across studies and allow for soundly supported policy decisions. The thesis addresses this issue by offering a set of recommendations for determining an appropriate model type based the load characteristics and study objectives.
\end{abstract}




\section{Acknowledgements}

The research in this thesis was funded by the U.S.-China Clean Energy Research Center (CERC) on Clean Vehicles, which is partially supported by the U.S. Department of Energy (Award No. DE-PI0000012) and its industry partners. This research is Project 5 within Thrust 6: Energy Systems Analysis, Technology Roadmaps and Policy, of the CERC Clean Vehicle Center.

This research would not have been possible without the guidance and expertise of my advisors, Dr. Gregory A. Keoleian and Dr. Jeremiah X. Johnson. I also received valuable feedback from Robb De Kleine, Dr. Geoffrey Lewis and my fellow researchers in the Center for Sustainable Systems at University of Michigan. 


\section{Table of Contents}

Acknowledgements ...................................................................................

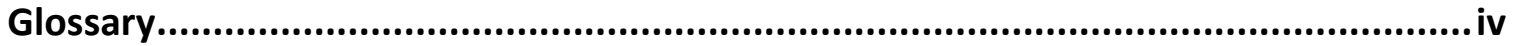

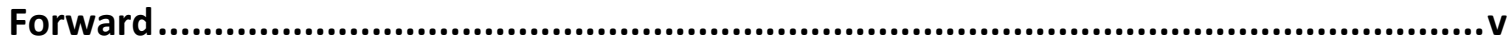

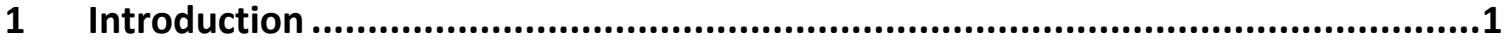

2 Literature Review and Characterization ...........................................................3

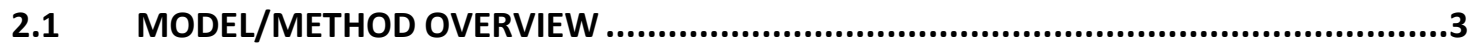

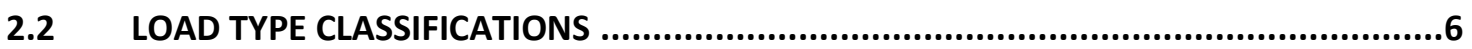

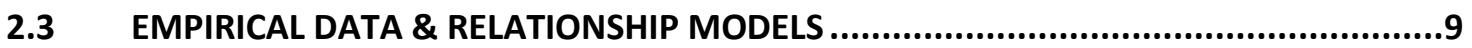

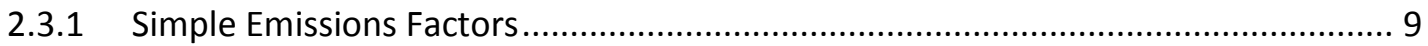

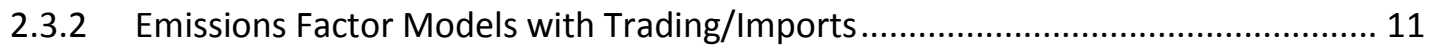

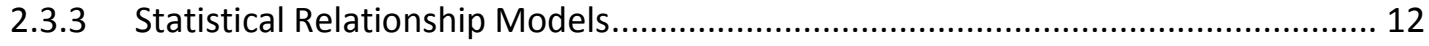

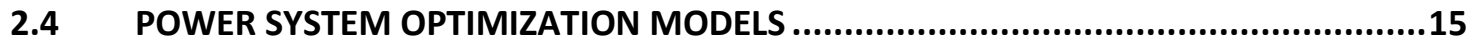

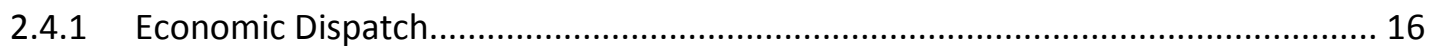

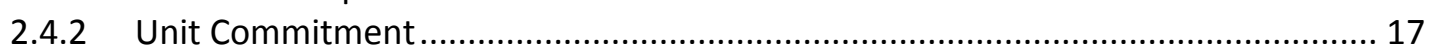

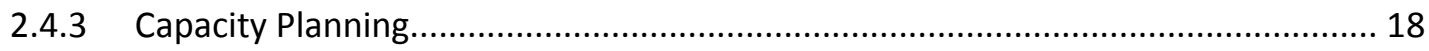

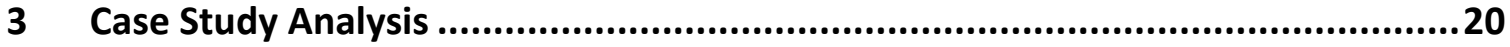

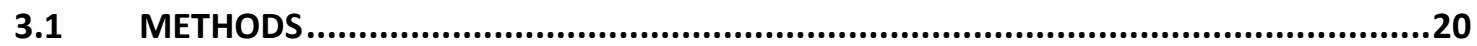

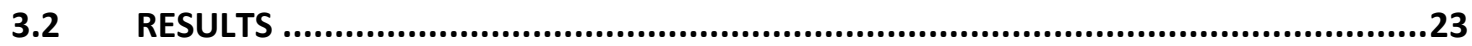

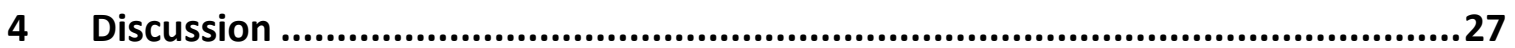

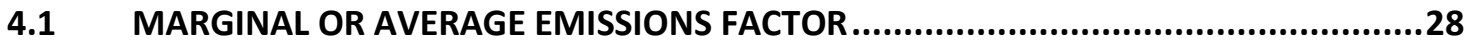

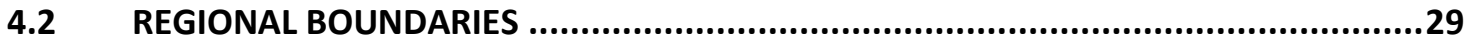

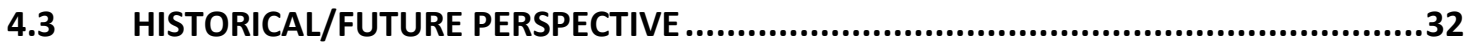

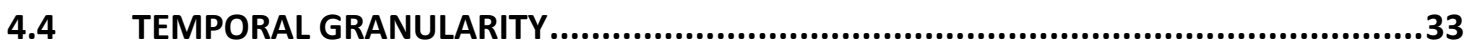

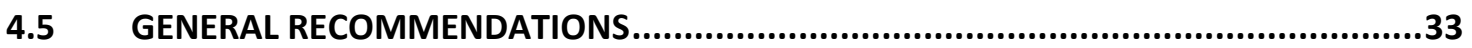

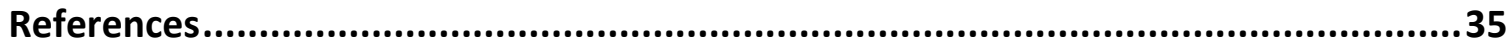

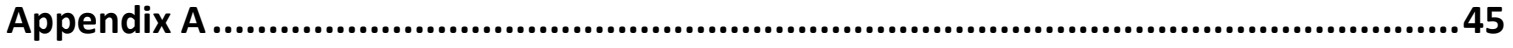




\section{Glossary}

Abbreviations

BA - Balancing Authority

CAFE - Corporate Average Fuel Economy

CAP - battery Capacity

$\mathrm{CF}$ - capacity factor

DOD - depth of discharge

ED - Economic dispatch

EERE - energy efficiency or renewable energy

$\mathrm{EF}$ - emissions factor

ERCOT - Electric Reliability Council of Texas

FERC - Federal Energy Regulatory Commission

Gen - generation

GHG - Greenhouse gas

ISO - Independent System Operator

MISO - Midcontinent

NERC - North American Electric Reliability Corporation

PCA - Power Control Area

SCED - security constrained economic dispatch

SOC - state of charge

$\mathrm{T} \& \mathrm{D}$ - transmission and distribution

$\mathrm{UC}$ - unit commitment

UCED - unit commitment economic dispatch

WMW - Upper Midwest

\section{$\underline{\text { Subscripts }}$}

$B$ - base case

$G$-generator level

$h$ - hour

$i$ - location

$N-$ new 


\section{Forward}

The work in this thesis was published in Environmental Science and Technology: Ryan, N.A., Johnson, J.X., and G.A. Keoleian, “Comparative Assessment of Models and Methods to Calculate Grid Electricity Emissions” Environmental Science \& Technology. Advanced online publication. DOI: 10.1021/acs.est.5b05216

This thesis was completed in conjunction with an Excel based tool, Selecting the appropriate Electricity Emissions Model (SEEM), developed to aid practitioners (e.g., researchers, policy analysts, Life-Cycle Assessment (LCA) analysts and consultants) in selecting the appropriate electricity modeling tool to estimate their electricity consumption emissions. The basis for the logic used in the tool is the recommendations provided at the end of this thesis. The tool is available for download at the Center for Sustainable Systems website. In addition, a paper presenting the decision support algorithm the tool uses will be submitted for publication. 


\section{Introduction}

In 2013, the electricity sector produced $31 \%$ of greenhouse gas (GHG) emissions in the United States ${ }^{1}$, making it the highest emitting economic sector. Emissions from electricity are a significant share of total emissions in many processes and in the production and use of many products. The motivation for this thesis is to understand the implications of method selection for evaluating power system emissions in order to educate practitioners completing sustainability assessments on the models available to them, how they differ in their assumptions and logic, as well as, how they can be appropriately applied. To develop this knowledge, the thesis details the methods' capabilities, limitations, and the disparity in the models' results. The models are first reviewed to identify key characteristics and assumptions, based on which they are classified into two distinct categories with six subcategories. We then assess an electric vehicle $(\mathrm{EV})$ case study using at least one model from each category to illustrate the variability in model results. Building on this information, the thesis provides guidance on the characteristics of methods that are required to appropriately calculate emissions from a given load.

Appropriately calculating electricity emissions associated with particular loads is necessary to determine the avoided emissions associated with improvements in energy efficiency, reductions in demand, improvements in product manufacturing, and increases in renewable generation, as well as for evaluating emissions associated with loads that increase electricity generation. Emissions calculations can determine the effectiveness of these actions at mitigating or exasperating climate change and other environmental harms.

Quantification of the emissions associated with a specific electric load presents a challenge due to power grid complexity. Tracing grid electricity consumption back to one generation source, in most cases, is not possible. ${ }^{2,3}$ A continuously changing mix of generation assets provides grid electricity. Additionally, with minimal storage on the grid, electricity production largely occurs at the same time as consumption. ${ }^{4,5}$ While research has produced a wide variety of proposed solutions in the form of models, methods, and 
metrics to measure the emissions from electricity generation, currently no consensus exists on an appropriate methodological approach for particular loads. ${ }^{2,3}$

The study of electric vehicles (EV) is one of the most prominent examples of inconsistency among methods used to estimate emissions from electricity consumption. The comparison of use phase emissions from plug-in EVs and conventional internal combustion engine vehicles (ICEV) is thoroughly studied. ${ }^{6-17}$ The breadth of studies illustrates a wide range of assumptions for charging profiles and methods to calculate grid emissions. These studies have found that the electricity mix significantly affects the emissions attributable to EVs' use phase, which accounts for the largest amount of GHG emissions of any phase in the vehicle's life. ${ }^{13,14,18-22}$ Anticipated growth in vehicle electrification and tougher GHG emissions and Corporate Average Fuel Economy (CAFE) standards elevate the importance of proper electricity emissions accounting. Various approaches selected to determine the emissions from grid-based electricity often yield significantly different results, which is very problematic given the significance of potential electricity emissions impacts. Axsen et al. compared three studies on PHEVs that used carbon intensities ranging from 200 to $1100 \mathrm{~g} \mathrm{CO}_{2} / \mathrm{kWh}$ due to differing model assumptions. ${ }^{23}$ Their study illustrates the importance of method selection to determining electricity production emissions.

Aluminum production is another sector where electricity usage proves significant to overall product emissions. ${ }^{24}$ Lightweighting a vehicle with aluminum can increase the miles per gallon of a conventional vehicle ${ }^{25}$ and possibly increase the miles per $\mathrm{kWh}$ of an EV, in turn reducing the energy consumption in the vehicle's use phase. However, depending on the fuel mix of the electricity used to make the aluminum, lightweighting a vehicle could cause divergent effects on life-cycle emissions. ${ }^{24}$ Increased emissions from electricity consumed to produce aluminum relative to steel could outweigh the reduction in emissions during the vehicle's use phase. ${ }^{24}$ The method used to determine the fuel mix of the electricity consumed is integral to the findings and to the ultimate attractiveness of vehicle lightweighting. ${ }^{24}$ Aluminum lightweighting and EV charging are two examples where electricity emissions are key to determining the GHG emissions of a technology. 


\section{Literature Review and Characterization}

\subsection{MODEL/METHOD OVERVIEW}

A variety of public and commercial assessment tools have been used to calculate emissions from electricity usage. They range in complexity, from simple emissions factors (EF) to multifaceted grid models with market-based dispatch of generation assets. For the purposes of this thesis, we have segmented the methods into two main categories, each further divided based on model characteristics. Table 1 contains the general descriptions of each category's characteristics.

Table 1. Emissions model categories

\begin{tabular}{|c|c|c|}
\hline Category & Characteristics & General Descriptions \\
\hline \multirow{3}{*}{$\begin{array}{l}\text { Empirical Data \& } \\
\text { Relationship Models }\end{array}$} & Simple Emissions Factors & $\begin{array}{ll}- & \text { Uses historical data for emissions and generation } \\
\text { - } & \text { Based on the ratio of emissions and generation over the selected time } \\
\text { frame } \\
\text { - } \quad \text { Based on specific region boundaries }\end{array}$ \\
\hline & $\begin{array}{l}\text { Emissions Factor Models } \\
\text { with Trading/Imports }\end{array}$ & $\begin{array}{l}\text { - Incorporates additional data and regional emissions factors to account for } \\
\text { electricity trading/imports }\end{array}$ \\
\hline & $\begin{array}{l}\text { Statistical Relationship } \\
\text { Models }\end{array}$ & $\begin{array}{l}\text { - Uses historical data to determine correlations between demand, past } \\
\text { emissions, generator operation, and other system characteristics to } \\
\text { develop emissions factors } \\
\text { - } \quad \text { EFs can be adjusted to reflect changes in load } \\
\text { - } \quad \text { Based on specific region boundaries }\end{array}$ \\
\hline \multirow{3}{*}{$\begin{array}{l}\text { Power System } \\
\text { Optimization Models }\end{array}$} & Economic Dispatch & $\begin{array}{l}\text { - Generators are dispatched based on operational costs to minimize overall } \\
\text { system costs or maximize company revenue } \\
\text { - } \quad \text { Predetermined or user defined regions/nodes } \\
\text { - } \quad \text { Requires generator-specific data }\end{array}$ \\
\hline & Unit Commitment & 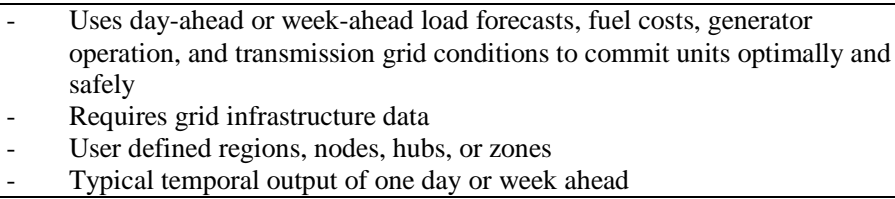 \\
\hline & Capacity Planning & $\begin{array}{ll}\text { - } & \text { Forecasts, or uses other model forecasts, for load \& fuel costs over } \\
\text { multiple decades to determine optimal generator or grid infrastructure } \\
\text { changes }\end{array}$ \\
\hline
\end{tabular}

Details about each model's load type, temporal granularity, time period (historical/current/future), regional resolution, imports/exports, and availability are presented in Table 2 and in further detail in the appendix. The bolded and highlighted methods are those used in the case study. 
Table 2. Models and methods to estimate emissions

\begin{tabular}{|c|c|c|c|c|c|c|}
\hline Method & Characteristics & $\begin{array}{l}\text { Temporal } \\
\text { Granularity }\end{array}$ & Perspective & Regional Resolution & $\begin{array}{l}\text { Regional } \\
\text { Imports/ } \\
\text { Exports }\end{array}$ & Availability \\
\hline \multicolumn{7}{|c|}{ EMPIRICAL DATA \& RELATIONSHIP MODELS } \\
\hline \multicolumn{7}{|l|}{ Average Emissions Factor Output } \\
\hline WattTime ${ }^{26}$ & $\begin{array}{l}\text { Simple Emissions } \\
\text { Factors }\end{array}$ & $\begin{array}{l}5 \text { min to } 1 \\
\text { hour }\end{array}$ & $\begin{array}{l}\text { Historical/ } \\
\text { Current }\end{array}$ & ISO/RTO Boundaries & No & $\begin{array}{l}\text { Website } \\
\text { Interface }\end{array}$ \\
\hline Colett et al. ${ }^{24}$ & $\begin{array}{l}\text { Emissions Factor } \\
\text { Models with } \\
\text { Trading/Imports }\end{array}$ & Yearly & Historical & $\begin{array}{l}\text { Combination BA \& } \\
\text { NERC }\end{array}$ & Yes & Literature \\
\hline Marriot, J. \& Matthews, S. ${ }^{27}$ & $\begin{array}{l}\text { Emissions Factor } \\
\text { Models with } \\
\text { Trading/Imports }\end{array}$ & Yearly & Historical & States & Yes & Literature \\
\hline Soimakallio, S. \& Saikku, L. ${ }^{28}$ & $\begin{array}{l}\text { Emissions Factor } \\
\text { Models with } \\
\text { Trading/Imports } \\
\end{array}$ & Yearly & Historical & Countries & Yes & Literature \\
\hline \multicolumn{7}{|c|}{ Marginal Emissions Factor Output } \\
\hline Holland et al. ${ }^{29}$ & $\begin{array}{l}\text { Statistical } \\
\text { Relationship }\end{array}$ & Hourly & Historical & 9 NERC regions & \begin{tabular}{|l|} 
None \\
between \\
interconnect \\
ions \\
\end{tabular} & Literature \\
\hline $\begin{array}{l}\text { AVoided Emissions and } \\
\text { geneRation Tool (AVERT) }\end{array}$ & $\begin{array}{l}\text { Statistical } \\
\text { Relationship }\end{array}$ & Hourly & Historical & $\begin{array}{l}\text { U.S. covered in } 10 \\
\text { regions }\end{array}$ & No & \begin{tabular}{|l|} 
Free \\
download \\
Excel \\
interface \\
\end{tabular} \\
\hline \multicolumn{7}{|c|}{ Average \& Marginal Emissions Factor Outputs } \\
\hline eGRID $31 a$ & $\begin{array}{l}\text { Simple Emissions } \\
\text { Factors }\end{array}$ & Yearly & Historical & $\begin{array}{l}\text { PCA/BA, subregions, } \\
\text { states, NERC \& U.S. } \\
\text { Average }\end{array}$ & No & $\begin{array}{l}\text { PDF Table of } \\
\text { Values }\end{array}$ \\
\hline Grid Mix Explorer 32 & $\begin{array}{l}\text { Simple Emissions } \\
\text { Factors }\end{array}$ & N/A & User defined & User defined & N/A & \begin{tabular}{|l|} 
Free \\
download \\
Excel \\
interface \\
\end{tabular} \\
\hline Siler-Evans et al..$^{33}$ & \begin{tabular}{|l} 
Statistical \\
Relationship \\
\end{tabular} & Hourly & Historical & 2010 NERC regions & No & Literature \\
\hline Zivin et al. ${ }^{7}$ & $\begin{array}{l}\text { Statistical } \\
\text { Relationship }\end{array}$ & Hourly & Historical & $\begin{array}{l}3 \text { interconnections } \\
\text { (emissions), } 2010 \\
\text { NERC (consumption) }\end{array}$ & \begin{tabular}{|l|} 
Varies if \\
consump. or \\
gen. data is \\
used
\end{tabular} & Literature \\
\hline Holland, S.P \& Mansur, E.T. ${ }^{34}$ & \begin{tabular}{|l} 
Statistical \\
Relationship
\end{tabular} & Hourly & Historical & 2004 NERC regions & Yes $^{b}$ & Literature \\
\hline Jansen et al..$^{35}$ & $\begin{array}{l}\text { Statistical } \\
\text { Relationship }\end{array}$ & Hourly & Historical & $\begin{array}{l}\text { Western } \\
\text { Interconnection }\end{array}$ & \begin{tabular}{|l|} 
between CA \\
and western \\
grid
\end{tabular} & Literature \\
\hline \multicolumn{7}{|c|}{ POWER SYSTEM OPTIMIZATION MODELS } \\
\hline \multicolumn{7}{|l|}{ Average Emissions Factor Output } \\
\hline $\begin{array}{l}\text { The Oak Ridge Competitive } \\
\text { Electricity Dispatch (ORCED) } \\
\text { Modelel6,37 }\end{array}$ & $\begin{array}{l}\text { Economic } \\
\text { Dispatch }\end{array}$ & Hourly & Future & $\begin{array}{l}\text { EIA Electricity Market } \\
\text { Module Regions } 2007\end{array}$ & Yes & $\begin{array}{l}\text { Oak Ridge } \\
\text { National Lab }\end{array}$ \\
\hline $\begin{array}{l}\text { The Integrated MARKAL- } \\
\text { EFOM System (TIMES) }{ }^{38,39}\end{array}$ & \begin{tabular}{|l|} 
Economic \\
Dispatch, \\
Capacity Planning \\
\end{tabular} & User defined & Future & User defined & Yes & IEA-ETSAP \\
\hline $\begin{array}{l}\text { Regional Energy Deployment } \\
\text { System (ReEDS) }{ }^{40-43}\end{array}$ & $\begin{array}{l}\text { Economic } \\
\text { Dispatch, } \\
\text { Capacity Planning }\end{array}$ & $\begin{array}{l}\text { Bi-yearlyc }, 17 \\
\text { annual time } \\
\text { slices }^{c}\end{array}$ & Future & $\begin{array}{l}356 \text { resource regions } \\
\text { grouped into } 4 \text { levels } \\
\text { of larger regions }\end{array}$ & Yes & $\begin{array}{l}\text { Created by } \\
\text { NREL for } \\
\text { research } \\
\text { purposes } \\
\end{array}$ \\
\hline \multicolumn{7}{|c|}{ Marginal Emissions Factor Output } \\
\hline $\begin{array}{l}\text { Electricity Dispatch model for } \\
\text { GHG Emissions in California } \\
\text { (EDGE-CA) }\end{array}$ & $\begin{array}{l}\text { Economic } \\
\text { Dispatch }\end{array}$ & Hourly & Historical & $\begin{array}{l}3 \text { regions in California } \\
w / 2 \text { external regions }\end{array}$ & Yes & Literature \\
\hline
\end{tabular}




\begin{tabular}{|c|c|c|c|c|c|c|}
\hline $\begin{array}{l}\text { Long-term Electricity Dispatch } \\
\text { model for GHG emissions in } \\
\text { California (LEDGE-CA) } \text { (23,44 }^{2}\end{array}$ & \begin{tabular}{|l|} 
Economic \\
Dispatch, \\
Capacity Planning \\
\end{tabular} & Hourly & Future & California & No & Literature \\
\hline Kim, J. D. \& Rahimi, M. 45 & $\begin{array}{l}\text { Economic } \\
\text { Dispatch }\end{array}$ & Hourly & Future & \begin{tabular}{|l} 
Los Angeles \\
Department of Water \\
\& Power \\
\end{tabular} & Yes & Literature \\
\hline $\begin{array}{l}\text { National Electric System } \\
\text { Simulation Integrated } \\
\text { Evaluator (NESSIE) })^{10,46,47}\end{array}$ & \begin{tabular}{|l|} 
Economic \\
Dispatch, \\
Capacity Planning \\
\end{tabular} & \begin{tabular}{|l}
6 Typical days \\
per year in 2 \\
hour blocks \\
\end{tabular} & Future & $\begin{array}{l}\text { EIA Electricity Market } \\
\text { Module Regions } 2007\end{array}$ & No & $\begin{array}{l}\text { Output data } \\
\text { for purchase } \\
\text { EPRI }\end{array}$ \\
\hline \multicolumn{7}{|c|}{ Average \& Marginal Emissions Factor Outputs } \\
\hline EnergyPLAN 48 & \begin{tabular}{|l|} 
Economic \\
Dispatch \\
\end{tabular} & Hourly & \begin{tabular}{|l|} 
Current/ \\
Future \\
\end{tabular} & User defined & Yes & Freeware \\
\hline $\begin{array}{l}\text { PJM Hourly Open-source } \\
\text { Reduced-form Unit- } \\
\text { Commitment Model } \\
\text { (PHORUM) }{ }^{49}\end{array}$ & \begin{tabular}{|l|} 
Security \\
Constrained, \\
Economic \\
Dispatch \\
\end{tabular} & Hourly & $\begin{array}{l}\text { Current/ } \\
\text { Future }\end{array}$ & $\begin{array}{l}\text { PJM (divided into } 5 \\
\text { regions) }\end{array}$ & $\begin{array}{l}\text { Among } 5 \\
\text { regions }\end{array}$ & Open-source \\
\hline $\mathrm{SCOPE}^{50}$ & \begin{tabular}{|l|} 
Security \\
Constrained, \\
Economic \\
Dispatch \\
\end{tabular} & Hourly & $\begin{array}{l}\text { Current/ } \\
\text { Future }\end{array}$ & User defined & Yes & $\begin{array}{l}\text { For purchase } \\
\text { Nexant }\end{array}$ \\
\hline Choi et al. ${ }^{51}$ & \begin{tabular}{|l|} 
Security \\
Constrained, \\
Economic \\
Dispatch, \\
Capacity Planning \\
\end{tabular} & Hourly & Future & $\begin{array}{l}6 \text { NERC regions in } \\
\text { eastern } \\
\text { interconnection (U.S.) }\end{array}$ & Yes & Literature \\
\hline AURORAxmp ${ }^{42}$ & \begin{tabular}{|l|} 
Security \\
Constrained, \\
Economic \\
Dispatch, \\
Capacity Planning \\
\end{tabular} & Hourly & Future & Nodal based & Yes & $\begin{array}{l}\text { For purchase } \\
\text { EPIS }\end{array}$ \\
\hline UPLAN-NPM ${ }^{41,46,52}$ & $\begin{array}{l}\text { Security } \\
\text { Constrained, } \\
\text { Economic } \\
\text { Dispatch } \\
\end{array}$ & Hourly & $\begin{array}{l}\text { Current/ } \\
\text { Future }\end{array}$ & Generator specific & Yes & $\begin{array}{l}\text { For purchase } \\
\text { LCG } \\
\text { Consulting }\end{array}$ \\
\hline GridView ${ }^{43}$ & \begin{tabular}{|l|} 
Security \\
Constrained, \\
Economic \\
Dispatch \\
\end{tabular} & Hourly & $\begin{array}{l}\text { Current/ } \\
\text { Future }\end{array}$ & User defined & Yes & $\begin{array}{l}\text { For purchase } \\
\text { ABB Inc. }\end{array}$ \\
\hline PLEXOS 53 & \begin{tabular}{|l|} 
Security \\
Constrained, \\
Economic \\
Dispatch, \\
Capacity Planning \\
\end{tabular} & $\begin{array}{l}\text { Hourly \& } \\
\text { Subhourly }\end{array}$ & Future & User defined & Yes & $\begin{array}{l}\text { For purchase } \\
\text { Energy } \\
\text { Exemplar }\end{array}$ \\
\hline $\begin{array}{l}\text { Promod IV } 54 \text { (Can be } \\
\text { integrated with Strategist) }{ }^{55}\end{array}$ & \begin{tabular}{|l|} 
Security \\
Constrained, \\
Economic \\
Dispatch \\
\end{tabular} & Hourly & $\begin{array}{l}\text { Current/ } \\
\text { Future }\end{array}$ & User defined & Yes & $\begin{array}{l}\text { For purchase } \\
\text { ABB Inc. }\end{array}$ \\
\hline $\begin{array}{l}\text { GE Multi Area Production } \\
\text { Simulation (MAPS) }\end{array}$ & \begin{tabular}{|l|} 
Security \\
Constrained, \\
Economic \\
Dispatch \\
\end{tabular} & Hourly & $\begin{array}{l}\text { Current/ } \\
\text { Future }\end{array}$ & User defined & Yes & $\begin{array}{l}\text { For purchase } \\
\text { GE }\end{array}$ \\
\hline GTMax $57-59$ & \begin{tabular}{|l} 
Economic \\
Dispatch
\end{tabular} & Hourly & Future & User defined & Yes & $\begin{array}{l}\text { For purchase } \\
\text { ADICA }\end{array}$ \\
\hline $\begin{array}{l}\text { Integrated Planning Model } \\
\text { (IPM) }\end{array}$ & \begin{tabular}{|l|} 
Economic \\
Dispatch, \\
Capacity Planning
\end{tabular} & Hourly & Future & $\begin{array}{l}64 \text { regions (covers all } \\
\text { U.S. states \& D.C.) } 11 \\
\text { Canadian regions }\end{array}$ & Yes & \begin{tabular}{|l|} 
Created by \\
EPA for \\
research \\
purposes \\
\end{tabular} \\
\hline $\begin{array}{l}\text { Strategist }{ }^{55} \text { (can be integrated } \\
\text { with Promod IV) }\end{array}$ & \begin{tabular}{|l|} 
Economic \\
Dispatch, \\
Capacity Planning
\end{tabular} & $\begin{array}{l}\text { Seasonal or } \\
\text { Annual }\end{array}$ & Future & User defined & Yes & \begin{tabular}{|l} 
For purchase \\
ABB Inc. \\
(comprised of \\
multiple \\
modules) \\
\end{tabular} \\
\hline
\end{tabular}

a) All eGRID emissions factors other than "non-baseload" are average and "non-baseload" can only be used as a rough estimation for marginal as described in the text

b) Temperature variables control for imports and exports

c) Model output time scale

d) Model analysis time scale 
The literature review and case study provided in this thesis focus on carbon dioxide emissions. Some of the methods and studies reviewed incorporate other emissions such as $\mathrm{PM}^{61}, \mathrm{VOC}, \mathrm{SO}_{2}, \mathrm{NO}_{\mathrm{x}}{ }^{29} \mathrm{Hg}, \mathrm{CH}_{4}$ and $\mathrm{CO}^{61}$. For example, eGRID provides $\mathrm{NO}_{\mathrm{x}}, \mathrm{SO}_{2}$, $\mathrm{CO}_{2}, \mathrm{CH}_{4}, \mathrm{NO}_{2}, \mathrm{Hg}$ and $\mathrm{CO}_{2}$-eq and AVERT provides $\mathrm{SO}_{2}, \mathrm{NO}_{\mathrm{x}}$ and $\mathrm{CO}_{2}{ }^{30}$. However, any U.S.-focused model that provides plant-specific data (e.g., generation, heat rate, fuel type) can be used to determine other criteria pollutants.

\subsection{LOAD TYPE CLASSIFICATIONS}

Emission factors (EFs) can be marginal (i.e., from generation used to supply an additional load or generators whose generation is reduced by removing a load) or average (i.e., from the entire generation mix). When a modeler uses average EF they are effectively assuming that the load has distributed burden on all power plants operating. ${ }^{62}$ Marginal emissions factors are used to describe the emissions associated with the generators whose outputs will change as a result of changes to load. Typically, marginal emissions are produced by a mixture of generation types, those with the highest variable costs of generators operating or the next units to be committed, which changes hourly, making them difficult to identify. ${ }^{63}$ The marginal units are also affected by the units providing baseload generation and whether they are flexible enough to provide the generation fluctuations and ancillary services needed to respond to demand and renewables' variability and uncertainty. For example, if the base load unit is coal and it cannot respond at a sufficient rate to meet rapid changes in demand, a natural gas plant could be added to the margin to meet this fluctuating demand.

Figure 1 illustrates two changes in load and their hypothetical effect on demand throughout a day. The hypothetical changes are caused by the addition of load from an EV fleet and the shutdown of an industrial facility. This example showcases the importance of temporal aspects of load changes with intra-day variation (EV charging) and flat output (industrial load), as well as the wide difference in results between average and marginal emissions factors. In figure 1c the average EF remains relatively flat while the marginal EF changes drastically depending on time of day. From 23:00-8:00 coal is 
on the margin, from 8:00-12:00 \& 21:00-23:00 natural gas combined cycles are on the margin, and from 10:00-21:00 natural gas combustion turbines are on the margin. 
a) - - - Industrial Facility Load - ----EV Fleet Load

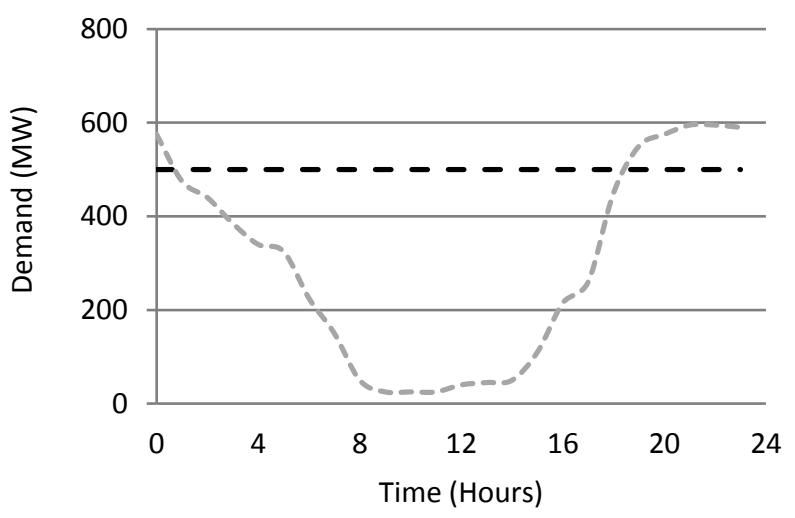

b) _ - - Base Case
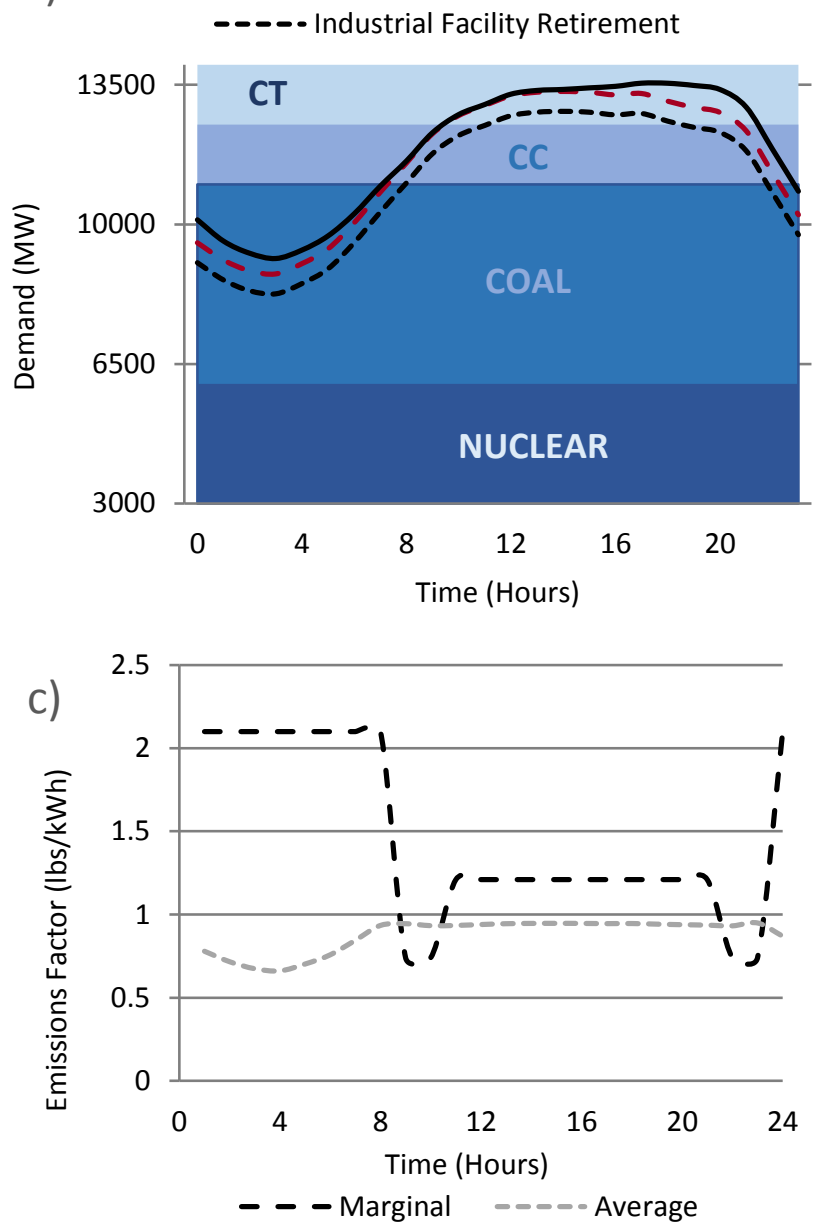

Figure 1. Average and marginal emissions factors for a change in electrical load across a daily load profile. a) the load profiles of the industrial facility and the electric vehicle fleet b) system-wide load decrease due to the shutdown of an industrial facility with constant demand and system-wide load increase due to the addition of an electric vehicle fleet with only home charging plotted over the system's generator supply stack, c) marginal and hourly average emissions factors for the daily load profile. For this illustrative example, we assume the following emissions factors: nuclear $=0 \mathrm{lb} / \mathrm{kWh}$; coal steam $=2.1 \mathrm{lb} / \mathrm{kWh}$; natural gas combined cycle $(C C)=0.74 \mathrm{lb} / \mathrm{kWh}$; natural gas combustion turbine $(\mathrm{CT})=1.21 \mathrm{lb} / \mathrm{kWh}$. 


\subsection{EMPIRICAL DATA \& RELATIONSHIP MODELS}

This category includes models that use historical data to either directly calculate emissions factors or to create models that predict generator operation or emissions based on load using probabilities or regressions. The region sizes and type of emissions factor used in these models vary. Additionally, select models in this category also incorporate electricity trading.

\subsubsection{Simple Emissions Factors}

Multiplying a published EF (either average or marginal) by a load or change in load represents the simplest and most commonly deployed method of assigning emissions burdens from electricity. We define 'simple emissions factors' as the ratio of emissions to generation over a defined time period using historical data. The historical emissions and generation for a set time period (e.g., year, hour) at plants across a given geographic or utility company-based boundary are employed without additional analysis to determine these EFs. ${ }^{62}$ The EPA's eGRID database provides tables of simple EFs for regions of varying size: individual generators, power control areas, states, eGrid subregions, North American Electric Reliability Corporation (NERC) regions, and the entire United States. ${ }^{64}$ The most recent database when this analysis was completed used 2010 data. ${ }^{31}$ The EPA's "total output" EF represents an average EF. Their "non-baseload" EFs, composed of emissions from combustion units with a capacity factor of less than 0.8 , was designed to provide improved emissions reductions estimates for energy efficiency and clean energy projects (i.e., consequential studies). ${ }^{65}$ Although these were intended for use in consequential studies, they are simply "non-baseload" EFs and therefore only represent a rough estimate for marginal EFs. The data inputs for the eGRID database include: EPA Clean Air Markets Annual and Ozone Season Emissions, Inventory of U.S. Greenhouse Gas Emissions and Sinks, FERC-714 report, and multiple EIA forms. ${ }^{31}$ The EPA provides a variety of emissions and renewable energy calculators that use eGRID data. ${ }^{31}$ Multiple studies have used the eGRID database to estimate emissions from electricity, alone or in conjunction with other sources: for example, Lewis et al.'s study on the life-cycle emissions from lightweight plug-in hybrid EVs, ${ }^{66}$ Amor et al.'s article on distributed generation, ${ }^{62}$ Graff Zivin et al.'s study on the spatial and temporal heterogeneity of 
marginal emissions, ${ }^{7}$ and MacPherson et al.'s study on PHEV emissions labeling. ${ }^{67}$ Tamayao et al. compared results from the methods Graff Zivin et al. and Siler-Evans et al. in different regions of the U.S. alongside emissions results from 2009 NERC regional averages and 2009 eGRID subregional averages, when calculating the life-cycle emissions of four vehicle types. ${ }^{68}$ Geo and Winfield used the U.S. average grid's mix with the incorporation of upstream fuel production impacts, transmission losses, and charging losses to compare GHG emissions from various drivetrains. ${ }^{69}$ Tessum et al. and Michalek et al. also used U.S. average as one of their electricity assumptions when assessing the life cycle air impacts of alternative vehicle fuels. ${ }^{61,70}$ Tessum et al. compared U.S. average emissions factor with natural gas, coal, wind turbines, dynamic water power or solar. ${ }^{70}$ Many of these studies along with others discussed in the appendix account for upstream emissions. Despite the methods in Table 2 being focused on use phase emissions, any models that provide the user with generator specific data or fuel type data can be combined with other models like GREET to calculate the upstream emissions.

EFs can also be calculated from a region's electricity mix and EFs specific to generating technologies and fuels, as was done in Buekers et al.'s study on the possible health benefits from a 5\% fleet replacement of ICEV to EVs in various European Union countries. ${ }^{71}$ Grid Mix Explorer by the National Energy Technology Laboratory provides EFs for new and existing generation technologies. ${ }^{32}$ CARMA provides the generation mix for countries around the world, ${ }^{72}$ used by Doucette and McCulluch in their comparison of PHEV and EV's $\mathrm{CO}_{2}$ emissions. ${ }^{11}$ Holdway et al. calculated average historical EFs for the U.S., UK, and France by simply dividing the total $\mathrm{CO}_{2}$ emissions from electricity production in each country by their net electricity generation, as part of a well-to-wheels emissions comparison of EVs, ICEVs, and HEVs as fleet vehicles. ${ }^{13}$ Other studies have used the average electricity mix of Belgium, ${ }^{73}$ Japan, the Netherlands, Iceland, China, India, ${ }^{15}$ or Germany. ${ }^{15,74}$

The Intergovernmental Panel on Climate Change (IPCC) also recommends using EFs when estimating emissions from stationary combustion electricity generators. ${ }^{75}$ However, they utilize a different type of EF, kilograms of emissions gas per terajoule of fuel combusted. ${ }^{75}$ 
The IPCC Emissions Factor Database reports these types of EFs for various fuels and technologies around the world from various sources. ${ }^{76}$ They split the methods for calculating electricity emissions into three tiers, each tier having a different level of generator aggregation, with Tier 3 being the least aggregated and Tier 1 the most. ${ }^{75}$ For example, Tier 1 uses non-technology or region specific EFs, Tier 2 uses country specific EFs and Tier 3 uses EFs based on specific generator technologies. ${ }^{75}$ They provide a decision tree on how to select the tier most appropriate for a user's application, much of it based on data availability. ${ }^{75}$

Another EF method, WattTime, uses data published by Independent System Operators (ISO) and Regional Transmission Organizations (RTO) to calculate a "real-time" estimate of EFs in various areas of the U.S. ${ }^{26}$ It was designed as a social tool that provides individuals their carbon intensities based on location. ${ }^{26}$ This is a valuable, simple, userfriendly tool to estimate emissions that reflects time of use. This approach, however, cannot predict future values and is geographically constrained due to the limited ISO and RTO coverage and data, which covers less than two-thirds of the geographic area of the United States. The specific type of data ISOs and RTOs provide varies but some examples include imports, exports, cost, and capacity reports. EFs are not directly provided.

Some literature-based studies also vary their EFs with time to incorporate a more appropriate representation of the emissions caused by EVs. Faria et al. is one example, they developed hourly EF profiles for each month in three countries to compare emissions from PHEV and BEV charging patterns to ICEVs emissions. ${ }^{12}$ Another is Nichols et al., they also used eGRID and National Emissions Inventory data on individual unit emissions rates along with ERCOT generation mix data to develop 15-minute interval emissions rate tables for each quarter of the year. ${ }^{77}$

\subsubsection{Emissions Factor Models with Trading/Imports}

Emissions factor models with trading/imports use historical generator operation data, with the addition of variables related to electricity imports and exports to create new EFs. In regions where a significant portion of electricity is imported from regions with varying 
generation mixes, these transactions can have a significant impact on the region's electricity EFs. ${ }^{78}$

Marriott and Matthews developed a model to determine emissions from a particular industry, while incorporating interstate trade of electricity using gross state consumption, gross generation, and grid losses. ${ }^{27}$ They used import-export data and a state distance matrix in an optimization, based on the assumption that electricity will be consumed in the closest demand location. ${ }^{27}$ Then they incorporate these electricity transfers into each state's energy mix, which was weighted by the percent of an industry's activity in the state to determine the industry's electricity consumption mixes. ${ }^{27}$ Colett et al. developed nested methods to study how the emissions from aluminum production varied by the location of production, considering imports and exports between the balancing authorities (BA) and the NERC region in which each BA is located, using the eGRID $\mathrm{CO}_{2}-$ eq EFs for the BA and NERC region. ${ }^{24}$ Soimakallio et al. calculated emissions intensities for OECD countries using a country consumption-based emissions method, with the inclusion of imports and exports. ${ }^{28}$ For their approach, the electricity exported from a country had the average yearly $\mathrm{CO}_{2}$ emissions intensity of that country. ${ }^{28}$ With this method, they showed that the emissions from net imports of electricity can have a significant effect on the overall emissions intensities of a given country and also that these intensities change from year to year. ${ }^{28}$ Overall, these methods attempt to provide EFs for the electricity consumed in a region that reflects the impacts of imports and exports. However, these approaches are still based on historical data and simplify grid interactions. Additionally, these models assess the effects of trading on average EFs and provide no guidance on incorporating the effects of electricity trading into marginal EFs.

\subsubsection{Statistical Relationship Models}

Statistical relationship models use historical data to determine correlations between demand, generator operations, emissions, and other system characteristics to develop regional EFs. Such models are retrospective in nature (i.e., relying on historical data) and not designed to respond to changes in fuel price or in infrastructure (e.g., generator or transmission additions), other than the addition of non-dispatchable renewables. The 
models often operate with generator-level granularity or aggregate by generator type based on fuel and prime mover. This characteristic provides more information about the grid system then most EF methods. Dispatching plants based on historical relationships between generation and load also implicitly incorporates electricity trading and implies that historical transmission constraints, generator costs, and operational limitations remain intact. ${ }^{30}$ AVoided Emissions and geneRation Tool (AVERT), created by Synapse Energy Economics, Inc. for the EPA, employs such an approach to determine the effects of energy efficiency and renewable energy policies on emissions. ${ }^{30}$ AVERT uses historical hourly plant data from the Air Markets Program to calculate the probability of each unit's operation during certain regional demand ranges. ${ }^{30}$ The user can download a dataset for their region and historical year of interest, which the tool uses to determine the fossil units that will be offset by an addition of renewable energy or a reduction in demand. ${ }^{30}$ Regions similar in size to NERC regions were also developed because limited effects of trading were expected. ${ }^{30}$ The model analyzes changes in load and how those changes affect fossil units, so the tool is not appropriate to develop average EFs. Additionally, the generating unit operational probabilities are based on a Monte Carlo method and AVERT specifies the smallest significant unit as a MW ${ }^{30}$ suggesting that AVERT may not be appropriate to analyze the effects of smaller projects. Despite these limitations, AVERT has more current data than other less complex methods available and it incorporates a user interface with simple inputs and multiple outputs that vary with time.

Archsmith et al. used 2011 and 2012 historical load, transmission and generation data to develop probabilities of operation, by generator type, to estimate the marginal emissions from charging an EV in each NERC region. ${ }^{79}$ Jansen at el. also correlated historical generation with load to create a statistical relationship model for the western grid, with a focus on California. ${ }^{35}$ Instead of assigning probabilities to individual units, they calculated hourly average capacity factors for resource groups (e.g., nuclear generators) and correlated those with system load. ${ }^{35}$ The resources were dispatched with and without the additional load from a fleet of PHEVs to develop the marginal and average emissions rates of PHEV penetration. ${ }^{35}$ 
Siler-Evans et al. developed a statistical relationship method for calculating marginal EFs, based on hourly historical continuous emissions monitoring system (CEMS) fossil-fuel generator data for eight NERC regions. ${ }^{33}$ Their model uses a linear regression of emissions and generation with a monthly and hourly resolution, as well as individual regressions for demand bins, each representing $5 \%$ of the demand data. ${ }^{33}$ Graff Zivin et al. used the relationship between hourly emissions, also from CEMS data, and end-use consumption within NERC regions to compare PEVs to conventional vehicles and demonstrate the effects of time of charge. ${ }^{7}$ Graff Zivin et al.'s method yielded hourly marginal EFs in the three major interconnections and each NERC region, by creating a regression between aggregated hourly interconnection emissions and regional (NERC) hourly demand data. ${ }^{7}$ The interconnections were employed for emissions to account for electricity trading between NERC regions within the interconnections.

Holland and Mansur's load variation emissions analysis model develops a relationship between emissions, average load, load variance, time, and temperature of nearby states as with other models using CEMs, FERC, and additional data sources. ${ }^{34}$ Their goal was to determine the effects of real time pricing on emissions. They categorized each hour as a high or low demand hour in a high or low demand day, then shifted demand from highload hours to low-load hours to simulate the effects real time pricing on demand and emissions. ${ }^{34}$ Along with developing emissions intensities, this study highlights the importance of temporal variation. Stephan et al. used Holland and Mansur's NERC region average emissions estimates when examining the short term emissions from charging a PHEV fleet with spare grid capacity. ${ }^{80}$ Holland et al. also developed an econometric model to estimate marginal emission factors by creating specific regressions between each individual power plant's hourly emissions and its NERC region's hourly load. ${ }^{29}$

Moreau et al. proposes another form of statistical analysis, kriging, for estimating uncertainties in life-cycle inventories, specifically the uncertainties related to electricity generation. ${ }^{81}$ Kriging is a minimum variance unbiased estimator originally developed to interpolate for random processes. ${ }^{81}$ 
Statistical relationship models reflect EFs associated with the actual historical performance of the electricity grid system. An advantage of this approach is that the operational constraints and complexities of the grid are reflected in the past performance of the system. Because these characteristics are reflected without modeling power system operations, calculation time and data requirements are reduced. This also presents a key limitation of such models: their reliance on historical data and past relationships limits their utility for modeling future grid operations that greatly differ from the past. Select models, like AVERT, include the ability to consider some changes in the electric grid supply or demand, but the results are still based on past data, including current or historical infrastructure, policies, and fuel prices. Thus, such models cannot be used to estimate future emissions if significant grid infrastructure, fuel price or energy policy changes are expected. However, statistical relationship models are often advantageous over simple EFs when a user's load varies with time or significant load changes are expected because statistical model designs can often reflect hourly variation in emissions or generator operation and changes in load.

\subsection{POWER SYSTEM OPTIMIZATION MODELS}

Unit commitment and economic dispatch models are employed in day-ahead and real-time markets to optimize expected generator operations. These models offer functionality in evaluating projected electricity generation operations, bound by physical laws of power generation and economic optimization. Capacity planning models have a longer view to optimize infrastructure investment decisions over time. The level of complexity and inclusion of operational constraints can vary greatly in both capacity planning and economic dispatch models with a selection of common variables listed in Table A1. The increased complexity in these models compared to other model types provides them the ability to offer the most realistic means to predict impacts of climate change mitigation policy, model infrastructure expansion planning, or forecast market changes. However, the large number of inputs these models require could represent a barrier to for their use and their complexity represents a significant hurdle for incorporation in LCA and footprinting research. The results of these models depend heavily on the input data and assumptions made by the user. Results for the same load could vary drastically when using the same model with different assumptions. 
This thesis divides the optimization models into three categories based on core functionality: economic dispatch, unit commitment, and capacity planning. Overlap exists between categories and the models used in industry often span these categories. Due to the importance of quality forecasting and its increasing difficulty with the growth of renewables, a large number of proprietary optimization models are available. The models in each category detailed in this thesis are listed in Table 2 and Table A2.

\subsubsection{Economic Dispatch}

Economic dispatch (ED) models determine generator output based on their relative cost of operation in order to minimize system cost, as influenced by fuel costs, transmission costs, unit efficiency, variable operations and maintenance costs, and other factors. The methods to determine the marginal unit and its cost can vary slightly with each model. Many dispatch models operate on an hourly basis while others like Strategist, NESSIE and ReEDS operate on a longer time frame because of their application in capacity planning. ${ }^{10,40,55}$

Academic ED models are often less complex in comparison to the commercial models but operate on the same principles. McCarthy et al. and Axsen et al. use the Electricity Dispatch model for Greenhouse gas Emissions in California (EDGE-CA) in their research, a spreadsheet-based ED model specific to California. ${ }^{6,23}$ They used the model to calculate the marginal emissions from electricity consumed by battery electric vehicles (BEV), PHEVs, and fuel cell vehicles in order to create a well-to-wheels comparison. ${ }^{6}$ Raichur $e t$ al. developed a short-term, historical, dispatch model for ERCOT and NYISO, which deployed plants in order of least cost within fuel type categories. ${ }^{82}$ They included and excluded operating constraints when calculating the marginal $\mathrm{CO}_{2}$ emissions of $\mathrm{EV}$ deployment to illustrate the importance of the constraints in creating a dispatch that closely resembles realistic operation. ${ }^{82}$ Kim and Rahimi quantified emissions from EVs in the Los Angeles Department of Water and Power service area under various charging scenarios and fleet infiltration rates. ${ }^{45}$ Their method also ranks the generation units in order of marginal cost, with the addition of renewable portfolio standards and the incorporation of 
upstream life-cycle emissions for each type of generation source. ${ }^{45}$ Vliet et al.'s method for the Netherlands operates nuclear, wind, PV, and combined heat and power first, when available, then operates the other units in order of variable operation and maintenance and fuel costs, typically resulting with natural gas-fired power plants on the margin. ${ }^{83}$ EnergyPLAN can incorporate the interactions between electricity, heat and transport fuels, making it an appropriate model to use when the generation mix includes a high percentage of combined heat and power or when incorporating "vehicle-to-grid" technology, as in Lund et al.'s study. ${ }^{84}$

Blumsack et al. developed an hourly ED model for PJM, ERCOT and MISO to assess the marginal emissions associated with a $30 \%$ fleet infiltration of PHEVs which charged during off-peak hours. ${ }^{85}$ They developed a short-run marginal cost curve for each region, which operated generators purely based on their heat rate and regional fuel prices. ${ }^{85}$ Newcomer et al. as well as Newcomer and Apt also developed short-run marginal cost curves in PJM, ERCOT, and MISO to dispatch generators. ${ }^{86,87}$ They used eGRID for generator data and regional fuel prices as did Blunmsack et al., adding average markups to account for additional costs related to transmitting the electricity. ${ }^{86,87}$ Peterson et al. used Newcomer et al.'s method when determining net air emissions from PHEVs in PJM and NYISO. ${ }^{17,87}$ Pacific Northwest National Laboratory assessed the emissions from charging PHEVs by developing a production cost dispatch, for summer and winter, which determines the units that will need to increase their capacity factor to meet the new load of the PHEVs. ${ }^{88}$ Based on the emissions rates of those units the model determines the total emissions from the required increase in load. ${ }^{88}$

\subsubsection{Unit Commitment}

Some models also solve the unit commitment (UC) problem to determine which units will be on or off in upcoming time periods. Minimum and maximum generator loads, ramp rates, flexibility, and other physical constraints may be used to determine these on-off decisions. The proprietary models in this group are dependent on data input by the user, including hourly demand profiles, market data, and transmission and distribution data. The user typically defines the outputs on a nodal/generator, hub, or zonal basis. 
All of the models in this category are also security constrained models, which take grid and generator forecasted conditions (e.g., transmission line capacities and generator outages) into consideration when dispatching units to optimize power flow. ${ }^{89}$ Methods in both the security constrained UC and ED categories are called Security Constrained Economic Dispatch Models (SCED), for example, SCOPE, AURORAxmp, UPLAN-NPM, GridView, PLEXOS, Promod IV, and GE MAPS. FERC defines a SCED as "the operation of generation facilities to produce energy at the lowest cost to reliably serve consumers, recognizing any operational limits of generation and transmission facilities". 89

Sioshansi and Denholm used a unit commitment model to calculate the changes in emissions caused by fleet PHEV deployment, with the incorporation of PHEV batteries for vehicle-to-grid services in the form of spinning reserves. ${ }^{90}$ This includes basic generator constraints, conventional generator costs, and PHEV operation costs. ${ }^{90,91}$ They calculated emissions using the UC model generation results and generator emissions rates, which included both fixed emissions rates, calculated from CEMs data, and variable rates, estimated using a non-parametric regression. ${ }^{92}$

\subsubsection{Capacity Planning}

We define capacity planning models as those that aim to optimize long-term infrastructure planning. Capacity planning models were among the first to rigorously optimize the grid system in the 1950s. ${ }^{93}$ While these models are not typically deployed to determine emissions impacts from changes in load, their ability to reflect infrastructure changes over long time horizons make them invaluable in assessing impacts over multiple decades. All of the capacity planning models listed in Table 2 consider the ED problem in some manner, but have additional functionally to determine optimal long-term (e.g., 25 years or more) infrastructure investments, such as transmission expansion or generation capacity changes. Such models can also be used to analyze the economic desirability and environmental effects of potential energy policies. AURORAxmp determines capacity expansion using a recursive optimization identifying resources, amongst current generating units and potential expansions with the highest and lowest future market values, in order to test future 
policies and create least cost future infrastructure expansion plans. ${ }^{93}$ ReEDs focuses on the effects of the increased use of renewables and the analysis of climate policies that could lead to further renewable penetration. ${ }^{40,41}$ Examples of ReEDS's applications include analyzing the least cost deployment and operation of utility resources in the case of a significant reduction in solar energy system costs ${ }^{43}$ or comparing the effects of proposed renewable electricity standards. ${ }^{94}$ Choi et al. developed a capacity planning model, which they used in coordination with an ED and UC model, to determine ways to reduce consumer expenditure when examining EV charging methods and fuel economy standards. ${ }^{51}$

Strategist, which was designed for integrated resource planning, ${ }^{55}$ along with other capacity expansion models, such as IPM and NESSIE, aggregate their smaller generators or those of the same type to increase efficiency of the model. ${ }^{10,55,60}$ NESSIE focuses on emissions changes related to future adjustments to the electric grid or generators. ${ }^{55}$ The National Energy Modeling System (NEMS) operates on a time horizon of 25 years, in order to analyze the impact of energy policies. ${ }^{92}$ It operates numerous supply, demand and conversion modules to develop these results, one of which is an electricity market module that operates on an ED. NEMs data are used to develop the Annual Energy Outlook (AEO), which provides the input data for models such as NESSIE, IPM, and Oak Ridge Competitive Electricity Dispatch (ORCED) ${ }^{36,41,46,60}$ ORCED model's ED operates using a modified Balleriaux-Booth procedure, ${ }^{36}$ (see ref. ${ }^{95}$ ). It uses NEMS to provide results out to $2030 .{ }^{95}$ ORCED does not attempt to determine appropriate new generation or infrastructure itself, but bases its supply on NEMS, eGRID and NEEDS databases. ${ }^{36}$ ORNL and Argonne National Laboratory both utilized ORCED to determine marginal electricity mixes and emissions for charging PHEVs. ${ }^{37,96}$

NEMS and NESSIE both have supply and demand as specified functions, which change as the model solves for equilibrium. ${ }^{41,46}$ They are used together in Oak Ridge National Lab's (ORNL) report, 'Power Transfer Potential to the Southeast in Response to a Renewable Portfolio Standard'. ${ }^{46}$ The Integrated MARKEL-EFOM System (TIMES) is also an equilibrium model that operates to maximize surplus and minimize costs. ${ }^{39}$ This bottomup model is typically applied to an overall energy sector policy analysis over long time 
horizons, but it can also be applied to single sectors like electricity. ${ }^{39}$ Babaee et al. utilized TIMES to study the effects of EVs on emissions and conditions under which high penetration could be achieved. ${ }^{38}$

\section{Case Study Analysis}

\subsection{METHODS}

To illustrate the impact of method selection on grid emissions, we calculate and compare emissions factors corresponding to several EV charging station locations, selected to provide diverse regional distribution. EV charging was selected as a case study for this analysis due to the importance of electricity mix on EV emissions, ${ }^{12,19}$ the increasing adoption of the vehicles, and the variation in past research methods and results.

We selected modeling methods based on the accessibility of the model, regional coverage of the model, data availability, and type diversity. We wanted to examine at least one model with each characteristic outlined in Table 1 to illustrate the wide range of results achieved across these disparate models. The methods used include six simple EF methods (U.S. Average, NERC, State, eGRID non-baseload subregion, eGRID subregion, Power Control Area/Balancing Authority), two EFs with trading (Import/Export Nested Average, Net Nested Average), one statistical relationship model (AVERT), and one UCED model (PLEXOS). A capacity planning model was not used due to the short time frame of the case study. The models are outlined in more detail in Table 2 .

The results present the $\mathrm{CO}_{2}$ emissions from operations, but do not include the upstream emissions related to fuel production and transportation. Estimates for the upstream emissions from the production of fossil fuels have been shown to have a much lower impact than those directly from combustion in the context of current generation mixes; 3,28 therefore the majority of fuel-cycle GHG emissions for EVs are a result of the electricity generation process. ${ }^{13,14,19,20}$ For all methods, we use 2010 data to match the EPA's most recent eGRID database. ${ }^{31}$ Three of the selected models, AVERT, PLEXOS, and eGRID non-baseload, provide marginal EFs or estimates of such in the case of eGRID nonbaseload, while the remaining models provide average EFs. ${ }^{30,31}$ Additionally, PLEXOS 
and AVERT are the only two methods of those compared quantitatively here that can incorporate the time variability of EV charging patterns. All other methods compared operate using yearly averages. However, all model types are included, not to advocate for their use but to show the range of outcomes they produce. In the discussion section we will examine the appropriateness of these methods.

The data for the nine EV charging stations examined in our case study are from the U.S. Department of Energy Alternative Fuels Database. ${ }^{97}$ The stations were selected to ensure representation of different states, NERC regions, eGRID subregions, and Power Control Area/Balancing Authorities (PCA/BA). We selected charging stations in Florida, Hawaii, Illinois, Kansas, Maine, Minnesota, Nevada, North Carolina, and Texas. Although, some charging stations have both EV1 and EV2 chargers, we assumed EV2 (240 V, 30 A) chargers were used, which operate at higher voltages than EV1 chargers allowing them to provide more energy to a vehicle in a shorter amount of time. The study employed each method listed above to determine the EFs (lbs. $\mathrm{CO}_{2} / \mathrm{kWh}$ ) for the selected stations. The values for each method, other than PLEXOS, AVERT, import/export nested average, and net nested average, came directly from eGRID's $9^{\text {th }}$ edition database.

To calculate EFs for the nested methods, we gathered values for total $\mathrm{CO}_{2}$ in $1 \mathrm{bs} / \mathrm{kWh}$ for the PCA and NERC region each charging station is located in from eGRID's $9^{\text {th }}$ edition. ${ }^{64}$ Colett et al. used $\mathrm{CO}_{2}$-eq values when completing their analysis but total $\mathrm{CO}_{2}$ values were used for this analysis in order to maintain consistency among methods. ${ }^{24}$ All 2010 import/export values came from FERC Form $714 .{ }^{98}$ Values for Rochester, MN and Alton, IL were not publically available due to MISO's aggregated reporting. The nested methods were then applied to these values to calculate EFs, using the approach detailed in ref. 24.

To calculate the marginal EFs from AVERT, we added $1 \mathrm{MW}$ of generation, which conforms with AVERT's significant figure requriements. ${ }^{30}$ Post-EERE (post-energy efficiency or renewable energy measure) and original emissions rates ${ }^{30}$ were used in Eq. 1 to calculate the yearly average marginal EFs for each location (i). Eq. 1 calculates the 
marginal EF for each hour $(h)$ then averages these to determine the yearly average value. The hourly marginal EFs are illustrated later in a comparison with PLEXOS in Figure 3.

$$
E F_{A V E R T, i}=\frac{1}{8760} \sum_{0}^{8760}\left(\frac{\text { Emissions }_{\text {Post EERE, },- \text { Emissions }_{\text {Original }, h}}}{\text { Gen }_{\text {Post EERE }, h}-\text { Gen }_{\text {Original }, h}}\right)
$$

A 5.5\% loss value was applied to the generation to convert from gross to net generation to align with other methods. ${ }^{99}$ Once all the methods' EFs were calculated or gathered, the location-specific maximum percent difference from average was calculated using Eq. 2.

$$
V_{M A X, i}=M A X\left|\frac{E F_{M E T H O D, i}-E F_{A V E R A G E, i}}{E F_{A V E R A G E, i}}\right|
$$

The last model compared in the case study was PLEXOS by Energy Exemplar, the most complex model employed. We used PLEXOS to determine the hourly emissions factors for one of the charging stations, located in Minnesota. PLEXOS was not used to calculate EFs for every charging station location due to calculation time limitations and the large data requirements. We employed assumptions identical to those in the base case of Johnson and Novacheck's analysis, ${ }^{78}$ with the exception of updating costs and system characteristics to match 2010 values for comparably to other models. The model assessed the Eastern Interconnection using integer programming with a 24-hour look ahead period using the Xpress-MP 25.01.05 solver. The marginal EFs for PLEXOS (EFPLEXOS,i,h) were not included in the method variation or regional average EFs, but were used to illustrate electricity emissions variations with time. The factors were calculated by first running a base case $(B)$ of the entire interconnection with 2010 load data. Then $1 \mathrm{MW}$ of load was added to a region of the Midcontinent Independent System Operator MOIL (MISO MOIL), a regional boundary defined in Johnson and Novacheck ${ }^{78}$, ref 78 , and the model was re-run to develop new $(N)$, hour (h), generator $(G)$ level emissions (Emissions $\mathrm{G}_{\mathrm{G}, \mathrm{N}, \mathrm{h}}$ ) and generation $\left(\mathrm{Gen}_{\mathrm{G}, \mathrm{N}, \mathrm{h}}\right)$ values. We assume that generators whose output increased represent the marginal units and whose emissions represent the marginal emissions, as detailed in Eq. 3.

$$
E F_{P L E X O S, i, h}=\frac{\sum_{0}^{G}\left(\text { Emissions }_{G, N, h}-\text { Emissions }_{G, B, h}\right)}{\sum_{0}^{G}\left(\text { Gen }_{G, N, h}-G_{G, B}\right)}
$$

AVERT and PLEXOS's hourly EFs were used to calculate the emissions per charge for four possible charging scenarios, beginning at $9 \mathrm{am}, 6 \mathrm{pm}, 10 \mathrm{pm}$ and $4 \mathrm{am}$. We assume that 
the vehicle starts charging at the beginning of each hour selected and continues to charge until the battery has reached $95 \%$ of capacity over 2.7 hours. The EFs for each hour or portion of an hour to charge the vehicle were substituted for $\mathrm{EF}_{\mathrm{h}}$ in Eq. 4 and averaged to determine the $\mathrm{lbs}$. $\mathrm{CO}_{2} /$ charge in each scenario. The total emissions from a complete vehicle charge at each station were calculated based on a constant charging rate and assumptions about the vehicle type and charging stations characteristics:

- $\quad$ Battery Capacity $(\mathrm{CAP})=24 \mathrm{kWh}$

- $\quad$ State of Charge (SOC) Range $=25 \%$ to $95 \%$ of full battery capacity ${ }^{100}$

- $\operatorname{Loss}_{\mathrm{T} \& \mathrm{D}}=6 \%{ }^{101}$

- $\quad$ Loss $_{\text {Charging Station }}=13 \%{ }^{102}$

The pounds of $\mathrm{CO}_{2}$ emissions per charge (lbs $\mathrm{CO}_{2} /$ charge) for each region equals the regional EFs previously defined $\left(\mathrm{EF}_{\mathrm{h}}\right)$ multiplied by the CAP and the difference in SOC divided by the charging station losses and transmission losses in Eq. 4.

$$
\mathrm{CO}_{2} \text { lbs./Charge }=\frac{\left(E F_{h}\right)(0.95-0.25)(C A P)}{\left(1-\text { Loss }_{\text {Charging Station })\left(1-\operatorname{LosS}_{T \& D}\right)}\right.}
$$

\subsection{RESULTS}

Figure 2 illustrates the variation in EF in each region by representing the data based on charging station location. This figure includes AVERT's hourly EFs averaged over the year to provide comparable results. The spread of the results in each location ranged from $0.21 \mathrm{lbs} . \mathrm{CO}_{2} / \mathrm{kWh}$ in Austin, TX to $1.4 \mathrm{lbs}$. $\mathrm{CO}_{2} / \mathrm{kwh}$ in Rochester, MN. Emissions factors for Rochester, MN and Alton, IL are absent for the Net Nesting and I/E Nesting methods due to lack of data.

The marginal EFs were, on average, $21 \%$ larger than the average EFs. Others have noted a similar trend, ${ }^{6,7}$ but not consistently. For example, Siler et al. calculated higher marginal EFs than average EFs in 5 out of the 8 NERC regions they assessed. ${ }^{33}$ Trends between average and marginal are not always in the same direction. ${ }^{33}$ However, low-carbon generation such as hydro, wind, and solar also have very low (or no) dispatch costs, making these units rarely marginal and driving the down the average EF. Additionally, the plants on the margin are higher in cost than those already running, ${ }^{6}$ possibly due to higher cost fuel or lower efficiencies. ${ }^{34,103}$ In a study of the U.S. Western Interconnection, the marginal 
emissions were calculated to be $40 \%$ higher than the average emissions, due mainly to natural gas peaker plants. ${ }^{35}$ In California in 2010, they were estimated to be $73-95 \%$ higher depending on time of day. ${ }^{2}$ In the UK, Ma et al. suggests that marginal emissions generally are $60 \%$ higher than average emissions. ${ }^{103}$ However, marginal emissions are not highest in each region, similar to the results found by Tamayao et al. that the magnitude and direction of the percent difference varies by region. ${ }^{68}$

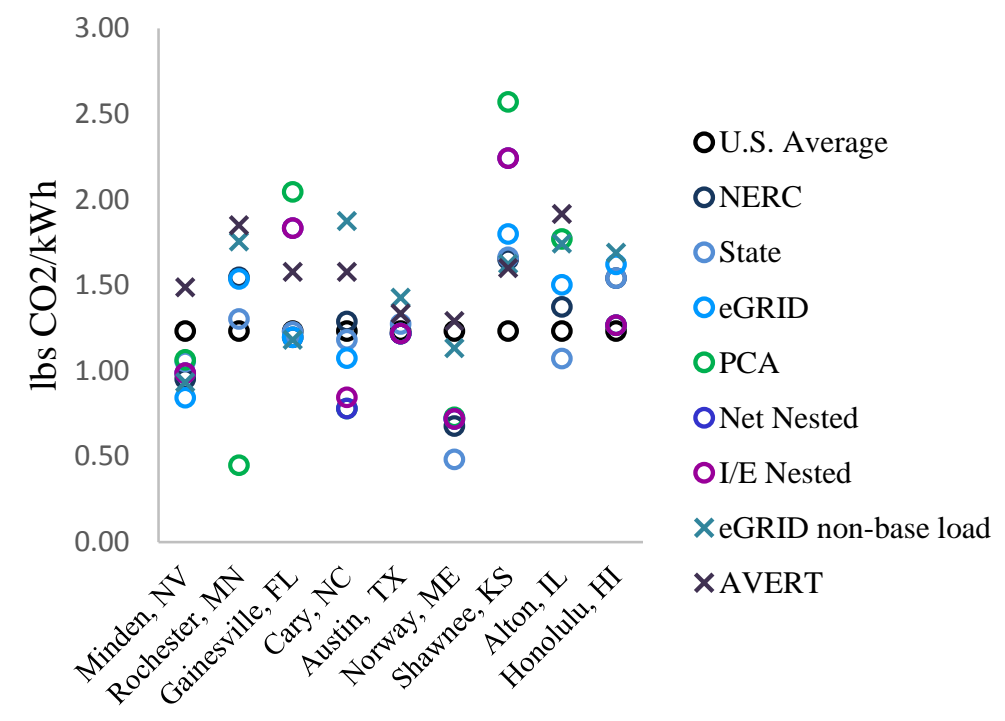

Figure 2. $\mathrm{CO}_{2}$ emissions, averaged across the year, per $\mathrm{kWh}$ based on charging station location [North American Electric Reliability Corporation (NERC), Power Control Area (PCA) $]^{64,97}$

We found that Rochester, MN's emissions factors had the largest percent difference from the average, at $69 \%$, driven by the PCA value being so much smaller than the average. This small emissions factor is driven by the generation mix in the region. Rochester, $\mathrm{MN}$ is located in the Southern Minnesota Municipal Agency PCA region, which generates 77\% of its electricity from wind power, modeled as a zero emissions electricity source. ${ }^{64}$ The impacts of imports and exports on this region are unknown, due to data unavailability. Due to the "must take" nature of wind generation and the related potential for fast variation in dispatchable generation, Southern Minnesota Municipal Agency region might have more significant imports or exports, which would likely make the PCA region emissions factor more similar to the results from other methods..$^{98}$ 
The Shawnee, KS PCA region value also differs greatly when compared to other methods. It is much larger than the average, at $2.57 \mathrm{lbs}$. $\mathrm{CO}_{2} / \mathrm{kWh}$, because it is a result of two large coal plants operating at lower capacity factors, which suggests less efficient partial load operation. ${ }^{64}$ Other estimates are lower because the region imports $36 \%$ and exports $30 \%$ of total electricity consumption to regions with lower average EFs. ${ }^{98}$ This trading is not incorporated into the EF calculation of the PCA. If it were included, the emissions factor would decrease as indicated by the results from the I/E nested and net nested EFs for the region.

The minimum percent difference from the mean occurred in Austin, TX (13.1\%), for which the NERC, State, eGRID subregion, and AVERT regional boundaries are very similar, so the power for charging can be linked to a single grid across each level. The Texas area is a mostly isolated power grid, ${ }^{77}$ composed almost entirely of the Electric Reliability Council of Texas (ERCOT), which is one of the three major U.S. interconnections. In the nesting methods less than $1 \%$ of electricity consumed is imported or exported out of the PCA, which matches the ERCOT ISO.${ }^{98}$ These examples illustrate the location-specific nature of what drives the variations in emissions factors across methods and regions. Two of the main location-specific factors are varying fuel mixes between spatial granularities, and high percentages of electricity imports and exports between regions coupled with large differences in EFs between regions.

The comparisons above, based on Figure 2, included marginal and average factors, which would not normally be compared since they answer two different questions, but in past research, both marginal and average factors have been used to assess emissions from the same electricity loads. We include this comparison to underscore the importance of matching the method to the research question. However, when comparing average factors alone large variation still exists. Among the average factors, the largest percent difference from the mean was $63 \%$ between the U.S. average and the mean for Norway, ME. When compared to the U.S., on average, New England ISO (i.e., Norway, ME's PCA) has a much smaller percentage of coal causing the other methods, with smaller regional boundaries, to have lower emissions factors. ${ }^{64}$ Variation among emissions factors suggests that even if 
your EF types and research questions are matched, there are a variety of ways to estimate the emissions factor that can lead to different outcomes.

AVERT and PLEXOS are unique among compared models in their ability to consider time variability. They are the only two models among those quantitatively compared that meet the recommended model requirements for estimating the emissions from current $\mathrm{EV}$ charging: ability to vary with time and estimate marginal emissions. Figure 3 illustrates the impact of seasonal and diurnal time variations for both of these methods.
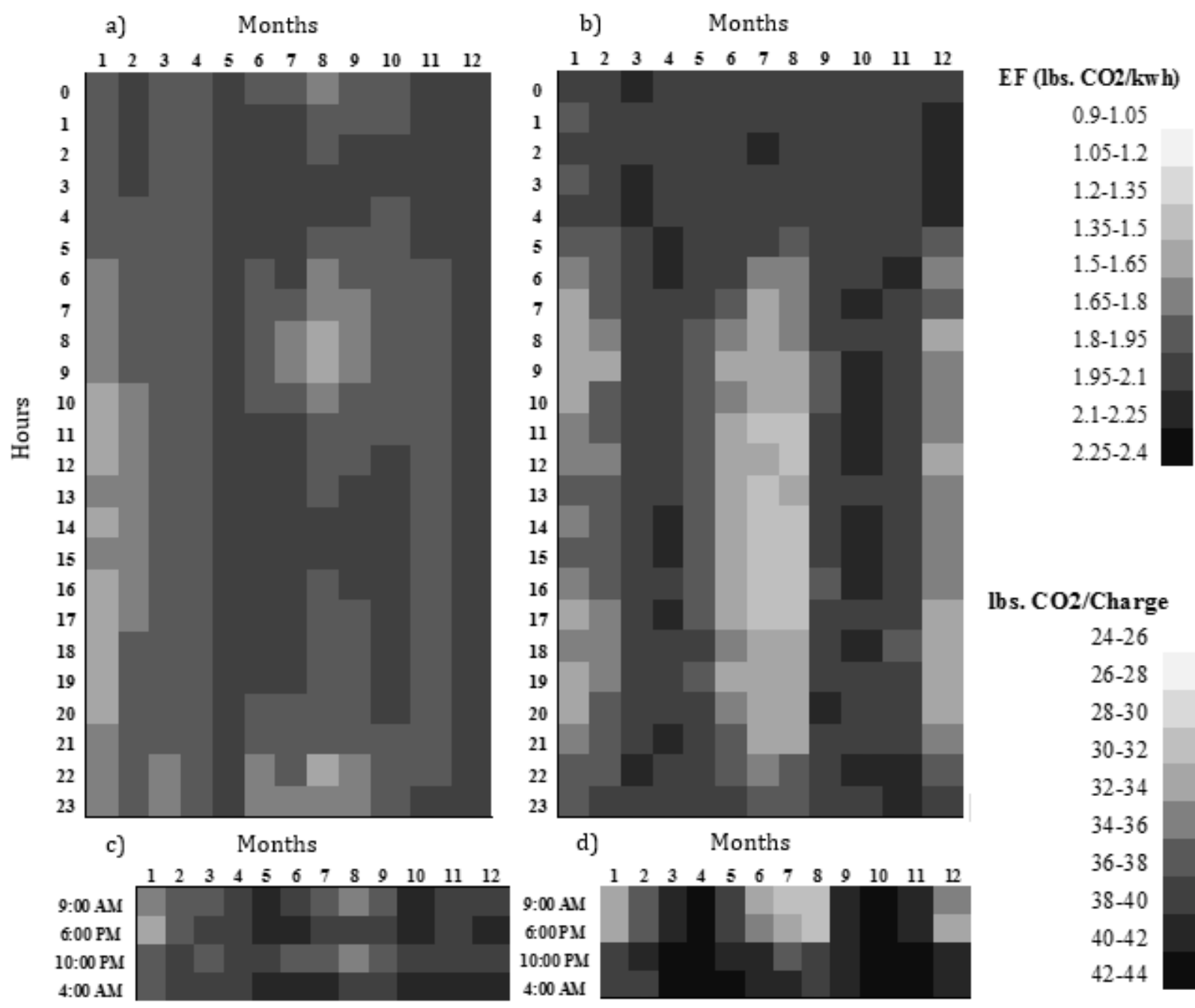

lbs. CO2/Charge

$24-26$

26-28

$28-30$

$30-32$

$32-34$

$34-36$

36-38

38-40

$40-42$

42-44

Figure 3. Hourly and monthly $\mathrm{CO}_{2}$ emissions produced from electric vehicle charging a) MISO MOIL (PLEXOS) hourly emissions factors, b) Upper Midwest (WMW) (AVERT) hourly emissions factors, c) MISO MOIL (PLEXOS) emissions per charge \& d) Upper Midwest (WMW) (AVERT) emissions per charge 
The marginal EFs and emissions per charge versus time result in different hourly trends depending on the month. There are also significant differences between the two methods, PLEXOS on the left and AVERT on the right. The AVERT Upper Midwest (WMW) region shows a fairly distinctive trend. Winter and summer have lower EFs during the daytime hours than in the fall and spring. This trend is not seen for the PLEXOS analysis and there is less variation in general. One major difference between AVERT and PLEXOS is the incorporation of trading, for AVERT the marginal units are in the region of interest but in the case of PLEXOS the marginal generation could be coming from another region, which may be causing the decreased variability in hourly EFs. However, the AVERT region is much larger than the one used in PLEXOS, yielding an imperfect but still useful comparison. The boundary used for the PLEXOS analysis was MISO MOIL, which is made up of mainly Illinois and parts of Missouri (more details found in Johnson \& Novacheck) while WMW contains parts of Illinois, Missouri, Wisconsin, Iowa, Minnesota, South Dakota, North Dakota and Nebraska. ${ }^{30,78}$

\section{Discussion}

This thesis illustrates the large array of approaches to estimate grid electricity emissions. The EV charging station case study vividly displays the wide range of possible results from these methods, underscoring the importance of method selection and the need for a consensus among the research community as to the appropriate methods to use for loads with particular characteristics. The variability of results seen is a direct impact of the assumptions employed by each method, making an understanding of these assumptions extremely important to method selection. The method selected to estimate emissions should be specifically tailored to the load of interest and the study's objective. Based on the results from the case study and the literature review, we offer several recommendations for selecting an appropriate model based on their characteristics and the features of the user's load and research question. These recommendations are organized based on the key characteristics from Table 2: marginal or average emissions factor, regional boundary, perspective, and temporal granularity. Table 3 summarizes key recommendations, with Sections 4.1-4.4 providing, justification, examples, and more details. 
Table 3. Recommendations on model characteristics required based on load features

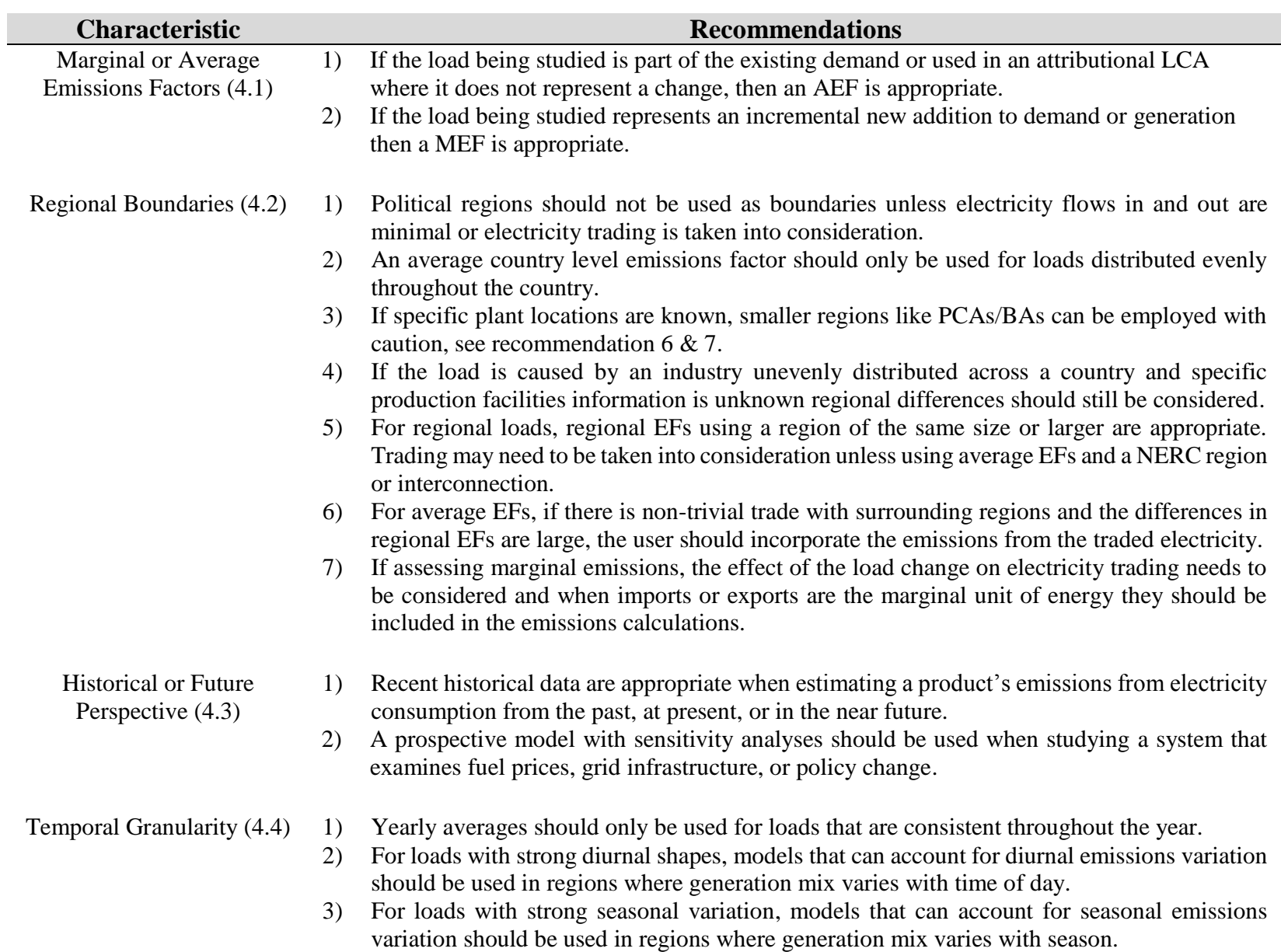

\subsection{MARGINAL OR AVERAGE EMISSIONS FACTOR}

A key decision when selecting the appropriate method for calculating grid emissions is whether to use a marginal factor or an average factor, which according to Yang is one of the most fundamental choices. ${ }^{2}$ These factors truly answer two separate research questions. Most simple emissions estimation methods use averages; therefore individuals employ average methods more commonly, ${ }^{7,33}$ and specifically in LCA. ${ }^{62,63}$ Returning to the example of electric vehicles, we see use of both average and marginal emissions factors. The Department of Energy's Beyond the Tailpipe Emissions calculator uses the average emissions rate from the eGRID2012 Version 1.0 Summary Tables. ${ }^{104}$ Additionally, Nichols et al. argue that due to the minimal penetration of EVs, emissions for a single vehicle represent the mix of all units generating at the time of charging, an average $\mathrm{EF}^{77}$ However, Zivin et al., Ma et al., Kim and Rahimi, Archsmith et al., and Tamayao et al. 
calculated marginal EFs for estimating use-phase emissions from EVs, with Zivin et al. stipulating that average EF approaches are "conceptually incorrect" and Tamayao et al. stipulating they are "conceptually inappropriate".7,45,68,79,103 McCarthy et al., and Elgowainy et al. uses a 'marginal electricity $\operatorname{mix}^{96}$ and 'marginal-generation mix'. 105 Equity can also influence allocation. Some consider it unfair to separate future and current consumption because existing consumption dictates the emissions from new consumption. ${ }^{4}$

In general, if the assumption is that the load in question represents part of the existing demand, then an average EF is more appropriate. If the load under analysis represents an incremental increase or decrease, marginal EFs can provide an emissions measurement specific to the change. Thus, for consequential LCAs of new loads, marginal factors are recommended $^{5}$ and for attributional LCAs of existing loads an average factor is recommended. The distinction is fundamentally about how the user's load interacts with the existing grid and the research question they are asking. For instance, the electricity consumption of existing EVs would not be considered a change, therefore using average EFs would be appropriate. For example, if the research question is "What share of grid emissions are EVs responsible for?", the researcher could justify the use of average EFs.

For added must-take renewable energy capacity, or a reduction in demand, the user should employ marginal EFs because the majority of output change will come from generators on the margin. For example, in SRVC Virginia/Carolina, the PCA region for Cary, NC, 41\% of the generation mix is nuclear and $55 \%$ is coal or natural gas, ${ }^{64}$ and the addition or subtraction of load would not typically impact the nuclear generation, but will more likely impact the coal or, most likely, natural gas fueled generators. This reality of grid operations is not reflected when researchers use average emissions factors to reflect the impact of changes in load. This is illustrated in the results with both marginal EFs being higher than the average EFs for Cary, NC.

\subsection{REGIONAL BOUNDARIES}

Selection of an appropriate regional boundary is another key consideration in calculating emissions due to the geographic variation in generation mixes, ${ }^{7,12,20,24,33}$ which are driven 
by an area's available resources, resource costs, demand profiles, and policy. ${ }^{6}$ At each charging station location, there was variation in the average EF for the PCAs, states, subregions, NERC regions, and the U.S. average. Even though these region sizes use the same methodology and data sources, the different regional boundaries drive a resulting difference in average EF. These results align with conclusions drawn by Weber et al. and Tamayao et al. ${ }^{3,68}$ Due to the importance of load consumption location, Wang et al. studied a locational marginal emissions methodology to shift the location of loads to reduce emissions, which succeeded in reducing emissions depending on the diversity of generators, spatial flexibility and $\mathrm{CO}_{2}$ pricing. ${ }^{105}$

Industries distributed evenly throughout the entire U.S. can use an EF for the U.S., but this distribution is atypical and overly applied. Some industries, aluminum production for example, are scattered heterogeneously across the U.S. If the sources of aluminum are unknown, then the use of multiple regions weighted by the concentration of aluminum production, similar to the method used by Marriot and Matthews, is preferable to using U.S. average emissions. ${ }^{27}$ If the user knows the location of a specific plant, then a smaller region like a PCA/BA may be employed. However, if imports are a large percentage of consumption and neighboring regions have a different generation mix, inaccurate bias toward the generators in the region could result. As observed in the case study, the variation in emissions estimates increased among the EF methods as the region size decreased, possibly relating in part to the PCA method not accounting for imports and exports of electricity. To minimize this bias, a method similar to the nested approach would be appropriate. ${ }^{24}$ If the user's load is regional, for example a regional increase in deployment of renewable generators, then a similar or slightly larger region should be selected.

Effectively modeling electricity trading requires an expanded system boundary to incorporate trading regions, as well as the incorporation of transmission constraints. These factors greatly increase modeling complexity. Studies have shown that incorporating electricity trading can affect the emissions results, with overall significance varying. ${ }^{24,27}$ Marriott and Mathews found incorporating interstate trading resulted in emissions closer to the U.S. average and a small difference between the industry emissions factor before 
and after interstate trading was incorporated. ${ }^{27}$ Colett et al. found, using the nested average and the import/export nested average method, that the EFs remained similar to the PCA average values ${ }^{24}$, which aligns with our results. When examining NERC regions, Holland et al. found that $80 \%$ of trade between control areas occurred within NERC regions. ${ }^{34}$ If states are used as boundaries, imports and exports become increasingly important because ten states import $25 \%$ or more of their electricity. ${ }^{67}$

In general, political regions (e.g., states \& countries), despite their convenience, do not represent suitable regional boundaries for EFs because they do not correlate with electricity interchanges. ${ }^{3,45,68}$ These boundaries should not be used unless electricity trading is taken into consideration. Johnson and Novacheck demonstrated that between $26 \%$ and $31 \%$ of emissions reductions from an expanded Renewable Portfolio Standard in Michigan would occur outside of the state. ${ }^{78}$ Even on a country level, electricity imports and exports can have a significant effect on emissions. In 2008, imports represented at least $30 \%$ of electricity consumption in seven OECD countries. $^{28}$ Overall, the importance of incorporating electricity trading varies depending on the modeling region. Based on the variation in significance of including electricity trading and the majority of trading occurring within NERC regions, it is reasonable to neglect electricity trading when using these regions in modeling.

Although, it is important that the user know the percent of electricity consumption that is imported, as well as the EFs of the surrounding regions, to ensure transparency. If the differences in regional EFs are large and the percent imports are non-trivial, emissions from the imported electricity need to be included to properly quantify changes in emissions. However, this analysis will only be effective when calculating average emissions. An addition in load could cause the regional demand to exceed the capacity or drive the marginal cost high enough that trading becomes economical. The trading would then be a consequence of the change in load meaning the emissions from the electricity traded should be attributed to the load. If the region from which electricity is imported has a significantly different $\mathrm{EF}$ from the region in which the load is located, then the trading is extremely important to consider. However, determining the effects a change in load will have on 
trading requires information on a number of variables (e.g., marginal costs of electricity, wheeling charges, regional capacity, regional demand, transmission capacity, etc.), and therefore can only be appropriately assessed by Power System Optimization Models.

Typically, it is difficult to generalize the importance of trading related to spatial resolution because the fraction of electricity consumed that is imported can vary significantly even between regions of the same type. Additionally, trading information is not always publically available for certain regional boundaries.

\subsection{HISTORICAL/FUTURE PERSPECTIVE}

Each model compared in the EV case study other than PLEXOS represents a historical perspective, meaning that past generation activity, grid infrastructure, and fuel prices determine EFs. AVERT allows the user to input "future" data sets to simulate "near-term" activity, which incorporates user adjusted plant additions and plant retirements but the other generating units' probabilities of dispatch remain based on past actions. ${ }^{30}$

Use of these historical relationships and outcomes should only be applied when modeling a load or a change in load that occurs in a system with infrastructure, policy and fuel prices consistent with the recent historical perspective. Such models are not appropriate to use when estimating the emissions reductions from future loads, load changes, or policies (i.e., higher energy efficiency standards or a more stringent Renewable Portfolio Standard). Future changes to the grid could significantly affect the EF of a region. Some of these changes could include unit retirement, new unit construction, transmission expansion, changes in fuel cost, environmental policies, and costs for emissions allowances. Such fundamental changes to the power system can, and do, occur over relatively short time periods, drastically changing power system operations and emissions. The charging impacts of an EV may change drastically over its life simply due to these structural changes to the power system. Therefore, when analyzing policies, processes, or products with a multi-year forward-looking view, a prospective dispatch model that includes functionality to incorporate such changes should be used to attain meaningful results, unless grid infrastructure, policy, and fuel prices are expected to remain largely unchanged over the 
time period of the analysis. However, as noted previously, prospective dispatch models are very sensitive to input assumptions and therefore completing sensitivity analyses is key to understanding how assumptions are affecting the emissions results.

\subsection{TEMPORAL GRANULARITY}

The importance of including temporal resolution varies based on the temporal variation of the load being modeled and the time span over which the user is interested in modeling (i.e., one day, one month etc.). eGrid bases EFs on yearly averages, which provides satisfactory results for industries that operate year round, at a constant load throughout the day. However, for electricity demand that has strong diurnal or seasonal variability, neglecting to include the time variation will provide unrealistic results ${ }^{8,12}$ in regions where the generation mix varies with time of day or season. ${ }^{62}$ This type of variation can be seen in the WMW AVERT region in Figure 3. If a load varies with time of day or there is interest in modeling specific hours of the day, a model that can output hourly emissions (e.g., AVERT, PLEXOS) should be used.

Many studies have found large variations in emissions with time. Zivin et al. found that when PEVs charged at night during off-peak hours, they produced more emissions than the average car on the road in certain areas of the U.S. ${ }^{7}$ Kim and Rahimi found similar results for the Los Angeles area. ${ }^{45}$ Additionally, Zivin et al. found marginal emissions for one hour within a day to be more than twice that of another hour in the same day. ${ }^{7}$ Typically the larger the portion of hydro or wind in the electricity mix, the more emissions vary with time. ${ }^{12}$ Siler-Evans et al.'s study found regional and seasonal differences in the time of day variance of $\mathrm{CO}_{2} \mathrm{EFs}$, but overall temporal differences were modest. ${ }^{33}$ This leads back to the idea that the importance of temporal variation depends not only on the load being modeled but also on the region in which it occurs.

\subsection{GENERAL RECOMMENDATIONS}

The EV case study and qualitative model review illustrate that there are gaps in the exiting emissions models and methods. A user friendly, freely available model does not yet exist for assessing applications like an EV fleet, which should include hourly variation in marginal EFs and a future perspective. None of the statistical models or EF models offer a 
future perspective, but the more complex models, like PLEXOS, can be too time intensive for research studies whose primary focus is not analyzing the grid. AVERT and PLEXOS are the only methods used in our case study that include temporal variation, however AVERT does not account for future market changes. Of the models quantitatively compared, only the nested methods and PLEXOS directly accounted for electricity imports and exports. These gaps can result in an over-generalization of the electricity sector modeling, as seen in some of the LCA literature.

A model to estimate emissions should be selected based on the load in question and the research question being asked. The recommendations outlined above can be a useful guide in selecting the appropriate model, but in many cases a model that fits all of an application's requirements will not exist. Users should employ various techniques to analyze sensitivities. Within the Power System Optimization Models, the user can run sensitivity analyses in ways that the empirical models do not allow for; however, the computational burdens, assumptions, and data requirements are large. Ultimately, it will be important to develop a consensus around the appropriate methods for calculating grid emissions for particular load types in order to make proportionate product, process, and policy comparisons. 


\section{References}

(1) U.S. Environmental Protection Agency. Inventory of U.S. Greenhouse Gas Emissions and Sinks: 1990-2013; 2015.

(2) Yang, C. Fuel electricity and plug-in electric vehicles in a low carbon fuel standard. Energy Policy 2013, 56, 51-62.

(3) Weber, C. L.; Jaramillo, P.; Marriott, J.; Samaras, C. Life Cycle Assessment and Grid Electricity: What Do We Know and What Can We Know? Supporting Information. Environ. Sci. Technol. 2010, 44 (6), 1-26.

(4) Soimakallio, S.; Kiviluoma, J.; Saikku, L. The complexity and challenges of determining GHG (greenhouse gas) emissions from grid electricity consumption and conservation in LCA (life cycle assessment) - A methodological review. Energy 2011, 36 (12), 6705-6713.

(5) Yang, C. A framework for allocating greenhouse gas emissions from electricity generation to plug-in electric vehicle charging. Energy Policy 2013, 60, 722-732.

(6) McCarthy, R.; Yang, C. Determining marginal electricity for near-term plug-in and fuel cell vehicle demands in California: Impacts on vehicle greenhouse gas emissions. J. Power Sources 2010, 195 (7), 2099-2109.

(7) Graff Zivin, J. S.; Kotchen, M. J.; Mansur, E. T. Spatial and temporal heterogeneity of marginal emissions: Implications for electric cars and other electricity-shifting policies. J. Econ. Behav. Organ. 2014, 107 (PA), 248-268.

(8) Keoleian, G.; Kelly, J.; MacDonald, J. Environmental Assessment of Plug-In Hybrid Electric Vehicles in Michigan. 2011.

(9) Samaras, C.; Meisterling, K. Life cycle assessment of greenhouse gas emissions from plug-in hybrid vehicles: implications for policy. Environ. Sci. Technol. 2008, 42 (9), 3170-3176.

(10) Electric Power Research Institute. Environmental Assessment of Plug-In Hybrid Electric Vehicles; 2007; Vol. 1.

(11) Doucette, R. T.; McCulloch, M. D. Modeling the prospects of plug-in hybrid electric vehicles to reduce CO2 emissions. Appl. Energy 2011, 88 (7), 2315-2323.

(12) Faria, R.; Marques, P.; Moura, P.; Freire, F.; Delgado, J.; De Almeida, A. T. Impact of the electricity mix and use profile in the life-cycle assessment of electric 
vehicles. Renew. Sustain. Energy Rev. 2013, 24, 271-287.

(13) Holdway, A. R.; Williams, A. R.; Inderwildi, O. R.; King, D. a. Indirect emissions from electric vehicles: emissions from electricity generation. Energy Environ. Sci. 2010, 3, 1825.

(14) Hawkins, T. R.; Gausen, O. M.; Strømman, A. H. Environmental impacts of hybrid and electric vehicles-a review. Int. J. Life Cycle Assess. 2012, 17 (8), 9971014.

(15) Nonaka, T.; Nakano, M. Study of popularization policy of clean energy vehicles using life cycle assessment. Next Gener. Infrastruct. Syst. eco-cities 2010, 1-6.

(16) Raykin, L.; Maclean, H. L.; Roorda, M. J.; Raykin, L.; Maclean, H. L.; Raykin, L.; Maclean, H. L.; Roorda, M. J. Implications of Driving Patterns on Well-to-Wheel Energy Use and Greenhouse Gas Emissions of Plug-in Hybrid Electric Vehicles. 2012, No. 416.

(17) Peterson, S. B.; Whitacre, J. F.; Apt, J. Net air emissions from electric vehicles: The effect of carbon price and charging strategies. Environ. Sci. Technol. 2011, 45 (5), 1792-1797.

(18) Cai, H.; Xu, M. Greenhouse gas implications of fleet electrification based on big data-informed individual travel patterns. Environ. Sci. Technol. 2013, 47 (16), 9035-9043.

(19) Hawkins, T. R.; Singh, B.; Majeau-Bettez, G.; Strømman, A. H. Comparative Environmental Life Cycle Assessment of Conventional and Electric Vehicles. $J$. Ind. Ecol. 2013, 17 (1), 53-64.

(20) Huo, H.; Cai, H.; Zhang, Q.; Liu, F.; He, K. Life-cycle assessment of greenhouse gas and air emissions of electric vehicles: A comparison between China and the U.S. Atmos. Environ. 2015, 108, 107-116.

(21) Meinrenken, C. J.; Lackner, K. S. Fleet view of electrified transportation reveals smaller potential to reduce GHG emissions. Appl. Energy 2015, 138, 393-403.

(22) Nordelöf, A.; Messagie, M.; Tillman, A. M.; Ljunggren Söderman, M.; Van Mierlo, J. Environmental impacts of hybrid, plug-in hybrid, and battery electric vehicles_-what can we learn from life cycle assessment? Int. J. Life Cycle Assess. 2014, 19 (11), 1866-1890. 
(23) Axsen, J.; Kurani, K. S.; McCarthy, R.; Yang, C. Plug-in hybrid vehicle GHG impacts in California: Integrating consumer-informed recharge profiles with an electricity-dispatch model. Energy Policy 2011, 39 (3), 1617-1629.

(24) Colett, J. S.; Kelly, J. C.; Keoleian, G. A. Using Nested Average Electricity Allocation Protocols to Characterize Electrical Grids in Life Cycle Assessment: A Case Study of U.S. Primary Aluminum Production. J. Ind. Ecol. 2015, 20 (1), 2941.

(25) Stodolsky, F.; Vayas, A.; Cuenca, R.; Gaines, L. Life-Cycle Energy Savings Potential from Aluminum- Intensive Vehicles by. In Total Life Cycle Conference \& Exposition; Argonne, IL, 1995; p 19.

(26) WattTime. WattTime API: FAQ https://api.watttime.org/faq/ (accessed Dec 10, 2015).

(27) Marriott, J.; Matthews, H. S. Environmental effects of interstate power trading on electricity consumption mixes. Environ. Sci. Technol. 2005, 39 (22), 8584-8590.

(28) Soimakallio, S.; Saikku, L. CO 2 emissions attributed to annual average electricity consumption in OECD (the Organisation for Economic Co-operation and Development) countries. Energy 2012, 38 (1), 13-20.

(29) Holland, S.; Mansur, E.; And, N. M.; Yates, A. Environmental benefits from driving electric vehicles? NBER Work. Pap. \#21291 2015.

(30) EPA. AVoided Emissions and geneRation Tool ( AVERT ) User Manual; 2014; Vol. Version 1.

(31) U.S. Environmental Protection Agency. The Emissions \& Generation Resource Integrated Database - Technical Support Document for the 9th Edition of eGRID with Year 2010 Data; Washington, DC, 2014.

(32) Shih, Chungyan; Cooney, Greg; Jamieson, Matt; Skone, T. J. Grid Mix Explorer (Model). National Energy Technology Laboratory 2015.

(33) Siler-Evans, K.; Azevedo, I. L.; Morgan, M. G. Marginal emissions factors for the U.S. electricity system. Environ. Sci. Technol. 2012, 46 (9), 4742-4748.

(34) Holland, S. P.; Mansur, E. T. Is Real-Time Pricing Green?: the Environmental Impacts of Electricity Demand Variance. Rev. Econ. Stat. 2008, 90 (3), 550-561.

(35) Jansen, K. H.; Brown, T. M.; Samuelsen, G. S. Emissions impacts of plug-in 
hybrid electric vehicle deployment on the U.S. western grid. J. Power Sources 2010, 195 (16), 5409-5416.

(36) Hadley, S.; Hirst, E. The oak Ridge Competitive Electricity Dispatch (ORCED) Model; Oak Ridge, TN, 2008.

(37) Hadley, S. W.; Tsvetkova, A. a. Potential Impacts of Plug-in Hybrid Electric Vehicles on Regional Power Generation; Oak Ridge, TN, 2008.

(38) Babaee, S.; Nagpure, A. S.; Decarolis, J. F. How much do electric drive vehicles matter to future U.S. emissions? Environ. Sci. Technol. 2014, 48 (3), 1382-1390.

(39) Loulou, R.; Remme, U.; Kanudia, A.; Lehtila, A.; Goldstein, G. Documentation for the TIMES Model Part I; 2005.

(40) Short, W.; Sullivan, P.; Mai, T.; Mowers, M.; Uriarte, C.; Blair, N.; Heimiller, D.; Martinez, A. Regional Energy Deployment System ( ReEDS); Golden, Colorado, 2011.

(41) Mcconnell, B. W.; Hadley, S. W. A Review of Barriers to and Opportunities for the Integration of Renewable Energy in the Southeast Prepared by; Oak Ridge, TN, 2011.

(42) EPRIS Inc. Presentations: Using AURORAxmp more effectively http://epis.com/xmp_in_action/presentations.php (accessed May 4, 2016).

(43) Brinkman, G.; Denholm, P.; Drury, E.; Ela, E.; Mai, T.; Margolis, R.; Mowers, M. Grid Modeling for the SunShot Vision Study; Golden, Colorado, 2012.

(44) McCarthy, R. W. Assessing Vehicle Electricity Demand Impacts on California Electricity Supply, University of California Davis, 2009.

(45) Kim, J. D.; Rahimi, M. Future energy loads for a large-scale adoption of electric vehicles in the city of Los Angeles: Impacts on greenhouse gas (GHG) emissions. Energy Policy 2014, 73 (2014), 620-630.

(46) Hadley, S. W.; Key, T.; Deb, R. Power Transfer Potential to the Southeast in Response to a Renewable Portfolio Standard: Interim Report 2; Oak Ridge, TN, 2009.

(47) EPRI. Translating Energy Efficiency into CO 2 Emissions Reduction : A Modeling Approach; Palo Alto, CA, 2011.

(48) Lund, H. EnergyPLAN - Advanced Energy Systems Analysis Computer Model. 
Documentation Version 12; 2015.

(49) Weis, A.; Michalek, J. J.; Jaramillo, P.; Lueken, R. Emissions and cost implications of controlled electric vehicle charging in the U.S. PJM interconnection. Environ. Sci. Technol. 2015, 49 (9), 5813-5819.

(50) Nexant. Nexant SCOPE Power System Anlaysis and Optimization http://server.nexant.com/ess/product_scope.aspx (accessed Apr 1, 2015).

(51) Choi, D. G.; Kreikebaum, F.; Thomas, V. M.; Divan, D. Coordinated EV adoption: Double-digit reductions in emissions and fuel use for \$40/vehicle-year. Environ. Sci. Technol. 2013, 47 (18), 10703-10707.

(52) LCG Consulting. Uplan Network Power Model http://www.energyonline.com/Products/Uplane.aspx (accessed Dec 1, 2014).

(53) Energy Exemplar. PLEXOS Integrated Energy Model http://energyexemplar.com/software/plexos-desktop-edition/ (accessed Dec 1, 2014).

(54) Ventyx an ABB Company. Product Overview: Promod IV Technical Overview http://new.abb.com/docs/librariesprovider139/default-document-library/promodiv-technical-overview_br.pdf?sfvrsn=2 (accessed Mar 22, 2015).

(55) Nanbu, P. H. Hawaiian Electric Companies' 2013 IRP Report and Action Plan; Honolulu, Hawaii, 2013.

(56) Hibbard, P. J.; Okie, A. M.; Tierney, S. F.; Darling, P. G. The Economic Impacts of the Regional Greenhouse Gas Initiative on Nine Northeast and Mid-Atlantic States; 2015.

(57) Elgowainy, a; Zhou, Y.; Vyas, a; Mahalik, M.; Santini, D.; Wang, M. Impacts of charging choices for plug-in hybrid electric vehicles in 2030 scenario. Transp. Res. Rec. 2012, No. 2287, 9-17.

(58) Final report of the GTMax Model review panel; Flagstaff, AZ, 2012.

(59) Veselka, T. GTMax Overview http://nebula.wsimg.com/ae6c576b97569c5a33d6630629af8165?AccessKeyId=1A 0D9A575B761BCFC58F\&disposition=0\&alloworigin=1 (accessed Mar 22, 2015).

(60) EPA. Documentation for EPA Base Case V.5.13 Using the Integrated Planning Model; Washington, DC, 2013. 
(61) Michalek, J. J.; Chester, M.; Jaramillo, P.; Samaras, C.; Shiau, C.-S. N.; Lave, L. B. Valuation of plug-in vehicle life-cycle air emissions and oil displacement benefits. Proc. Natl. Acad. Sci. 2011, 108 (40), 16554-16558.

(62) Amor, M. Ben; Gaudreault, C.; Pineau, P.-O.; Samson, R. Implications of integrating electricity supply dynamics into life cycle assessment: A case study of renewable distributed generation. Renew. Energy 2014, 69, 410-419.

(63) Lund, H.; Mathiesen, B. V.; Christensen, P.; Schmidt, J. H. Energy system analysis of marginal electricity supply in consequential LCA. Int. J. Life Cycle Assess. 2010, 15 (3), 260-271.

(64) EPA. eGRID 9th edition version 1.0, Year 2010 Summary Tables; Washington, DC, 2014.

(65) Rothschild, S. S.; Diem, A. Guidance on the Use of eGRID Output Emission Rates; Washington, DC \& Springfield, VA, 2008.

(66) Lewis, A.; Kelly, J.; Keoleian, G. Evaluating the life cycle greenhouse gas emissions from a lightweight plug-in hybrid electric vehicle in a regional context. In 2012 IEEE International Symposium on Sustainable Systems and Technology (ISSST); 2012; pp 1-6.

(67) Macpherson, N. D.; Keoleian, G. a.; Kelly, J. C. Fuel Economy and Greenhouse Gas Emissions Labeling for Plug-In Hybrid Vehicles from a Life Cycle Perspective. J. Ind. Ecol. 2012, 16 (5), 761-773.

(68) Tamayao, M.-A. M.; Michalek, J. J.; Hendrickson, C.; Azevedo, I. M. L. Regional Variability and Uncertainty of Electric Vehicle Life Cycle CO2 Emissions across the United States. Environ. Sci. Technol. 2015, 49 (14), 8844-8855.

(69) Gao, L.; Winfield, Z. C. Life cycle assessment of environmental and economic impacts of advanced vehicles. Energies 2012, 5 (3), 605-620.

(70) Tessum, C. W.; Hill, J. D.; Marshall, J. D. Life cycle air quality impacts of conventional and alternative light-duty transportation in the United States. Proc. Natl. Acad. Sci. U. S. A. 2014, 111 (52), 18490-18495.

(71) Buekers, J.; Van Holderbeke, M.; Bierkens, J.; Int Panis, L. Health and environmental benefits related to electric vehicle introduction in EU countries. Transp. Res. Part D Transp. Environ. 2014, 33, 26-38. 
(72) CARMA. National CO2 intensity data http://www.carma.org/ (accessed Jun 2, 2015).

(73) Messagie, M.; Boureima, F.; Matheys, J.; Sergeant, N.; J-m, T.; Macharis, C.; J, V. M. Environmental performance of a battery electric vehicle : a descriptive Life Cycle Assessment approach. World Electr. Veh. J. 2010, 4, 782-786.

(74) Held, M.; Baumann, M. Assessment of the Environmental Impacts of Electric Vehicle Concepts. In Toward Life Cycle Sustainability Managment; Finkbeiner, M., Ed.; 2011; pp 535-546.

(75) Garg, A.; Pulles, T. Volume 2: Energy. In 2006 IPCC Guidelines for National Greenhouse Gas Inventories; Eggleston, S., Buendia, L., Miwa, K., Ngara, T., Tanabe, K., Eds.; Hayama, Japan, 2006.

(76) IPCC NGGIP. Main Page http://www.ipcc-nggip.iges.or.jp/efdb/main.php (accessed Jul 25, 2015).

(77) Nichols, B. G.; Kockelman, K. M.; Reiter, M. Air quality impacts of electric vehicle adoption in Texas. Transp. Res. Part D Transp. Environ. 2015, 34, $208-$ 218.

(78) Johnson, J. X.; Novacheck, J. Emissions reductions from expanding state-level renewable portfolio standards. Environ. Sci. Technol. 2015, 49 (9), 5318-5325.

(79) Archsmith, J.; Kendall, A.; Rapson, D. From Cradle to Junkyard: Assessing the Life Cycle Greenhouse Gas Benefits of Electric Vehicles. Res. Transp. Econ. 2015, 52, 72-90.

(80) Stephan, C. H.; Stephan, C. H.; Sullivan, J.; Sullivan, J. Environmental and energy implications of plug-in hybrid- electric vehicles. Environ. Sci. Technol. 2008, 42 (4), 1185-1190.

(81) Moreau, V.; Bage, G.; Marcotte, D.; Samson, R. Estimating Material and Energy Flows in Life Cycle Inventory with Statistical Models. J. Ind. Ecol. 2012, 16 (3), 399-406.

(82) Raichur, V.; Callaway, D. S.; Skerlos, S. J. Estimating Emissions from Electricity Generation Using Electricity Dispatch Models: The Importance of System Operating Constraints. J. Ind. Ecol. 2015, 20 (1), 42-53.

(83) Van Vliet, O.; Brouwer, A. S.; Kuramochi, T.; Van Den Broek, M.; Faaij, A. 
Energy use, cost and CO2 emissions of electric cars. J. Power Sources 2011, 196 (4), 2298-2310.

(84) Lund, H.; Kempton, W. Integration of renewable energy into the transport and electricity sectors through V2G. Energy Policy 2008, 36 (9), 3578-3587.

(85) Blumsack, S.; Samaras, C.; Hines, P. Long-term electric system investments to support Plug-in Hybrid Electric Vehicles. In IEEE Power and Energy Society 2008 General Meeting: Conversion and Delivery of Electrical Energy in the 21st Century; Pittsburg, PA, 2008; pp 1-6.

(86) Newcomer, A.; Apt, J. Near-term implications of a ban on new coal-fired power plants in the United States. Environ. Sci. Technol. 2009, 43 (11), 3995-4001.

(87) Newcomer, A.; Blumsack, S. a.; Apt, J.; Lave, L. B.; Morgan, M. G. Short run effects of a price on carbon dioxide emissions from U.S. electric generators. Environ. Sci. Technol. 2008, 42 (9), 3139-3144.

(88) Kintner-Meyer, M.; Schneider, K.; Pratt, R. Impacts Assessment of Plug-In Hybrid Vehicles on Electric Utilities and Regional U.S. Power Grids Part 1: Technical Analysis. Online J. EUEC 2007, 1-20.

(89) Federal Energy Regulatory Commission. Security Constrained Economic Dispatch: Definition, Practices, Issues and Recommendations; 2006.

(90) Sioshansi, R.; Denholm, P. Emissions Impacts and Benefits of Plug-In Hybrid Electric Vehicles and Vehicle-to-Grid Services Emissions Impacts and Benefits of Plug-In Hybrid Electric Vehicles and Vehicle-to-Grid Services. 2009, 43 (4), 1199-1204.

(91) Sioshansi, R.; Denholm, P. The Value of Plug-In Hybrid Electric Vehicles as Grid Resources Plug-In Hybrid Electric Vehicle Technology. 34th IAEE Int. Conf. Stock. Sweden 2011.

(92) Energy Information Administration. The National Energy Modeling System: An Overview 2009; Washington, DC, 2009.

(93) Foley, A. M.; Ó Gallachóir, B. P.; Hur, J.; Baldick, R.; McKeogh, E. J. A strategic review of electricity systems models. Energy 2010, 35 (12), 4522-4530.

(94) Sullivan, P.; Logan, J.; Bird, L. Comparative Analysis of Three Proposed Federal Renewable Electricity Standards Comparative Analysis of Three Proposed Federal 
Renewable Electricity Standards; Golden, Colorado, 2009.

(95) Vardi, J.; Avi-Ithak, B. Electric Energy Generation Economics, Reliability, and Rates; MIT Press: Cambrige, MA, 1981.

(96) Elgowainy, A.; Burnham, A.; Wang, M.; Molburg, J.; Rousseau, A. Well-toWheels Energy Use and Greenhouse Gas Emissions Analysis of Plug-in Hybrid Electric Vehicles; Argonne, IL, 2009.

(97) U.S. Department of Energy. Electric Vehicle Charging Station Locations http://www.afdc.energy.gov/data (accessed Oct 22, 2015).

(98) FERC. Form No. 714 - Annual Electric Balancing Authority Area and Planning Area Report; Washington, DC, 2010.

(99) U.S. Energy Information Administration. Annual Energy Review: Electricity Flow, 2014; 2014.

(100) Marano, V.; Onori, S.; Guezennec, Y.; Rizzoni, G.; Madella, N. Lithium-ion batteries life estimation for plug-in hybrid electric vehicles. Veh. Power Propuls. Conf. 2009. VPPC '09. IEEE 2009, 536-543.

(101) U.S. Energy Information Administration. Frequently Asked Questions http://www.eia.gov/tools/faqs/faq.cfm?id=105\&t=3 (accessed Nov 1, 2014).

(102) Duvall, M. Comparing the Benefits and Impacts of Hybrid Electric Vehicle Options for Compact Sedan and Sport Utility Vehicles; Palo Alto, CA, 2002.

(103) Ma, H.; Balthasar, F.; Tait, N.; Riera-Palou, X.; Harrison, A. A new comparison between the life cycle greenhouse gas emissions of battery electric vehicles and internal combustion vehicles. Energy Policy 2012, 44, 160-173.

(104) U.S. Department of Energy. Sources and Assumptions for the Electric and Plug-in Hybrid Vehicle Greenhouse Gas Emissions Calculator http://www.fueleconomy.gov/feg/label/calculations-information.shtml (accessed Dec 11, 2014).

(105) Wang, Y.; Wang, C.; Miller, C. J.; McElmurry, S. P.; Miller, S. S.; Rogers, M. M. Locational marginal emissions: Analysis of pollutant emission reduction through spatial management of load distribution. Appl. Energy 2014, 119, 141-150.

(106) Soimakallio, S.; Kiviluoma, J.; Saikku, L. The complexity and challenges of determining GHG (greenhouse gas) emissions from grid electricity consumption 
and conservation in LCA (life cycle assessment) - A methodological review. Energy 2011, 36 (12), 6705-6713.

(107) Wang, M.; Wu, Y.; Elgowainy, A. Operating Manual for GREET: Version 1.7. 2007, 154.

(108) Cai, H.; Wang, M.; Elgowainy, A.; Han, J. Updated Greenhouse Gas and Criteria Air Pollutant Emission Factors and Their Probability Distribution Functions for Electric Generating Units; Argonne, IL, 2012.

(109) Michalek, J. J.; Chester, M.; Jaramillo, P.; Samaras, C.; Shiau, C.-S. N.; Lave, L. B. Valuation of plug-in vehicle life-cycle air emissions and oil displacement benefits. Proc. Natl. Acad. Sci. U. S. A. 2011, 108 (40), 16554-16558.

(110) Gaines, L.; Burnham, A.; Rousseau, A.; Santini, D. Sorting through the many total-energy-cycle pathways possible with early plug-in hybrids; Argonne, IL, 2007.

(111) Querini, F.; Morel, S.; Boch, V.; Rousseaux, P. Global, regional and local environmental impacts: LCA indicators for energy \& mobility; Berlin, 2011. 


\section{Appendix A}

\section{Upstream Electricity Emissions}

Although this thesis's focus is on direct emissions from the production of electricity, much of the literature that utilizes EFs to determine the GHG emissions from EVs also incorporates the upstream emissions from the feedstock recovery and processing prior to combustion. Yang argues that these emissions are critical to include when making transportation fuel comparisons ${ }^{2}$ but other studies assert that they have a much lower emissions impact than those directly from combustion. ${ }^{28,106}$ Many of the studies which incorporate the upstream emissions use the GREET model to attain these values. GREET incorporates four options for entering the electricity generation mix, U.S. average electricity mix being the first. ${ }^{2,107}$ The values for generation mix are derived from EIA projections. ${ }^{107}$ The fuel type and combustion technology EFs are calculated from eGRID unit level emissions and plant performance data, which is derived from the Clean Air Markets Division (CAMD). ${ }^{108}$ Michalek et al. used a base case of average U.S. grid emissions, as part of an LCA analysis, using eGRID and GREET data sources to determine emissions from HEVs, PHEVs and EVs. ${ }^{109}$ They then put bounds on their factors by using a zero emissions grid and a grid consisting of all coal fired power plants. ${ }^{109}$ Meinrenken and Lackner used a similar method, by presenting results across a wide range of emissions intensities they can account for regional and temporal variation, avoid the debate of marginal vs. average EFs, and simplify their analysis. ${ }^{21}$ Gaines et al. compared various fuel pathways for PHEVs, in terms of electricity, also with varying the fuel sources from coal to Wind \& PV. ${ }^{110}$ Querini et al. used an all coal EF and an electricity mix of 50\% coal and $50 \%$ renewable to illustrate the importance of electricity mix. ${ }^{111}$ Raykin et al. looked at electricity generated from $100 \%$ hydroelectricity, 100\% natural gas, $100 \%$ coal and the average Ontario electricity mix. ${ }^{16}$ They employed sole generation technologies to investigate the vehicles environmental performance in cases when those units were marginal, although the article notes that during the PHEV's life the marginal electricity will likely not be generated by one fuel type. ${ }^{16}$ 
Table A1. Possible variables methods/tools incorporate

\begin{tabular}{|c|c|c|}
\hline & Market Data & $\begin{array}{l}\text { Fuel prices } \\
\text { LMP } \\
\text { Market rules } \\
\text { Emission prices } \\
\text { Electricity demand (hourly) }\end{array}$ \\
\hline $\begin{array}{l}\text { System } \\
\text { Representation }\end{array}$ & $\begin{array}{l}\text { Generator Level Data } \\
\text { (Aggregated or generator } \\
\text { specific) }\end{array}$ & $\begin{array}{l}\text { Ramp rate } \\
\text { Max output } \\
\text { Min output } \\
\text { Fuel type } \\
\text { Prime mover technology } \\
\text { Heat rate } \\
\text { Availability factor } \\
\text { Losses } \\
\text { Emissions/kwh } \\
\text { Historical operating trends } \\
\text { Minimum run time } \\
\text { Non-fuel costs } \\
\text { Environmental compliance costs }\end{array}$ \\
\hline & Transmission \& Distribution Data & $\begin{array}{l}\text { Interchange restraints } \\
\text { Demand locations } \\
\text { Transmission outages } \\
\text { Overall grid topology } \\
\text { Losses (regionally or calculated based on grid infrastructure) }\end{array}$ \\
\hline Spatial Resolution & Regional boundary & $\begin{array}{l}\text { Size } \\
\text { Geographic or company based } \\
\text { Isolated from surrounding regions or able import and export electricity }\end{array}$ \\
\hline & Retrospective & $\begin{array}{l}\text { Historical imports/exports } \\
\text { Historical generator operation data } \\
\text { Past demand patterns and load variation }\end{array}$ \\
\hline $\begin{array}{l}\text { Temporal } \\
\text { Resolution }\end{array}$ & Prospective & $\begin{array}{l}\text { Predictions of future infrastructure change (addition of generators, retirement } \\
\text { of generators, grid infrastructure improvements, asset performance) } \\
\text { Predictions for renewable technology improvements and cost reduction } \\
\text { Predictions of future fuel prices } \\
\text { Yearly, seasonally, hourly, } 5 \text { min data output data } \\
\text { Future demand predictions }\end{array}$ \\
\hline $\begin{array}{l}\text { Policy } \\
\text { Incorporation }\end{array}$ & \multicolumn{2}{|c|}{$\begin{array}{l}\text { Carbon tax or cap and trade considerations } \\
\text { Current/future regional RE or EE policies }\end{array}$} \\
\hline $\begin{array}{l}\text { Additional } \\
\text { Variables }\end{array}$ & \multicolumn{2}{|l|}{ Weather data } \\
\hline
\end{tabular}


Table A2. Emissions estimation protocols quantitatively compared

Emissions Estimation Protocol
U.S. Average
NERC
State
eGRID non-baseload subregion
eGRID subregion
Power Control Area/Balancing Authority
AVERT
Import/Export Nested Average
Net Nested Average
PLEXOS

Table A3. Charging station locations $\mathbf{s}^{30,31,64,97}$

$\begin{array}{lllllll}\text { Station ID } & \text { City } & \text { State } & \text { NERC } & \text { eGRID } & \text { AVERT } & \text { PCA/BA } \\ 60173 & \text { Minden } & \text { NV } & \text { WECC } & \text { NWPP } & \text { NW } & 210 \\ 60879 & \text { Rochester } & \text { MN } & \text { MRO } & \text { MROW } & \text { WMW } & 256 \\ 50012 & \text { Gainesville } & \text { FL } & \text { FRCC } & \text { FRCC } & \text { SE } & 172 \\ 47718 & \text { Cary } & \text { NC } & \text { SERC } & \text { SRVC } & \text { SE } & 157 \\ 41769 & \text { Austin } & \text { TX } & \text { TRE } & \text { ERCT } & \text { TX } & 165 \\ 62640 & \text { Norway } & \text { ME } & \text { NPCC } & \text { NEWE } & \text { NE } & 185 \\ 47928 & \text { Shawnee } & \text { KS } & \text { SPP } & \text { SPNO } & \text { SC } & 187 \\ 51747 & \text { Alton } & \text { IL } & \text { RFC } & \text { RFCW } & \text { WMW } & 107 \\ 49009 & \text { Honolulu } & \text { HI } & \text { HICC } & \text { HIOA } & \text { N/A } & 178\end{array}$

Table A4. Emissions factors by location and method ${ }^{64}$

\begin{tabular}{|c|c|c|c|c|c|c|c|c|c|c|c|}
\hline ID & City, State & $\begin{array}{c}\text { U.S. } \\
\text { Average }\end{array}$ & NERC & State & $\begin{array}{c}\text { eGRID } \\
\text { non- } \\
\text { base } \\
\text { load } \\
\end{array}$ & eGRID & PCA & AVERT & $\begin{array}{c}\text { Net } \\
\text { Nested } \\
\end{array}$ & $\begin{array}{c}\mathrm{I} / \mathrm{E} \\
\text { Nested }\end{array}$ & PLEXOS \\
\hline 60173 & Minden, NV & 1.23 & 0.95 & 1.05 & 0.93 & 0.84 & 1.06 & 1.49 & 0.99 & 0.99 & - \\
\hline 42188 & $\begin{array}{l}\text { Rochester, } \\
\text { MN }\end{array}$ & 1.23 & 1.55 & 1.30 & 1.76 & 1.54 & 0.45 & 1.85 & - & - & 1.90 \\
\hline 50012 & $\begin{array}{c}\text { Gainesville, } \\
\text { FL }\end{array}$ & 1.23 & 1.20 & 1.23 & 1.18 & 1.20 & 2.05 & 1.58 & 1.83 & 1.83 & 1.90 \\
\hline 47718 & Cary, NC & 1.23 & 1.29 & 1.18 & 1.87 & 1.07 & 0.78 & 1.58 & 0.78 & 0.85 & 1.87 \\
\hline 41769 & Austin, TX & 1.23 & 1.22 & 1.27 & 1.43 & 1.22 & 1.22 & 1.33 & 1.22 & 1.22 & - \\
\hline 62640 & Norway, ME & 1.23 & 0.68 & 0.48 & 1.13 & 0.72 & 0.73 & 1.29 & 0.72 & 0.72 & 1.90 \\
\hline 47928 & Shawnee, KS & 1.23 & 1.65 & 1.66 & 1.62 & 1.80 & 2.57 & 1.60 & 2.24 & 2.24 & 1.89 \\
\hline 51747 & Alton, IL & 1.23 & 1.37 & 1.07 & 1.74 & 1.50 & 1.77 & 1.92 & - & - & 1.88 \\
\hline 49009 & Honolulu, HI & 1.23 & 1.54 & 1.54 & 1.69 & 1.62 & 1.27 & - & 1.27 & 1.27 & - \\
\hline
\end{tabular}


Table A5. Maximum variation in emissions estimation factors from the location mean EF

$\begin{array}{lcc} & \begin{array}{c}\text { Average }\left(\mathrm{lbs} . \mathrm{CO}_{2} / \mathrm{kwh}\right) \\ \mathrm{EF}_{\mathrm{AVERAGE,i}}\end{array} & \begin{array}{c}\text { Max } \% \text { Variation from Mean } \\ \mathrm{V}_{\mathrm{MAX}, \mathrm{i}}\end{array} \\ \text { Location, } i & 1.06 & 40.4 \% \\ \text { Minden, } \mathrm{NV}^{\mathrm{a}} & 1.38 & 67.6 \% \\ \text { Rochester, MN* } & 1.48 & 38.1 \% \\ \text { Gainesville, FL } & 1.18 & 58.6 \% \\ \text { Cary, NC } & 1.26 & 13.1 \% \\ \text { Austin, } \mathrm{TX}^{\mathrm{a}} & 0.86 & 50.8 \% \\ \text { Norway, } \mathrm{ME} & 1.85 & 39.2 \% \\ \text { Shawnee, } \mathrm{KS} & 1.52 & 29.3 \% \\ \text { Alton, IL* } & 1.43 & 18.3 \% \\ \text { Honolulu, HI**a } & * \text { Values do not include nested average data or I/E Nested Average data } \\ \quad \text { ** The Honolulu, HI metrics do not include AVERT data } \\ \quad \text { a Values do not include PLEXOS data } \\ \text { Note: These calculations averaged both marginal and average emissions facto }\end{array}$




\section{Table A6. Summary of models and methods reviewed}

\begin{tabular}{|c|c|c|c|c|c|c|c|c|}
\hline Method & Characteristics & Availability & $\begin{array}{l}\text { Regional } \\
\text { Granularity }\end{array}$ & $\begin{array}{l}\text { Time } \\
\text { Period }\end{array}$ & $\begin{array}{c}\text { Temporal } \\
\text { Granularity }\end{array}$ & $\begin{array}{l}\text { Regional } \\
\text { Imports/ } \\
\text { Exports } \\
\end{array}$ & $\begin{array}{c}\text { Marginal/ } \\
\text { Average }\end{array}$ & Output Data \\
\hline WattTime $^{26}$ & $\begin{array}{l}\text { Simple Emissions } \\
\text { Factors }\end{array}$ & Website Interface & $\begin{array}{l}\text { ISO/RTO } \\
\text { Boundaries }\end{array}$ & $\begin{array}{l}\text { Historical/ } \\
\text { Current }\end{array}$ & $\begin{array}{l}5 \text { min to } 1 \\
\text { hour }\end{array}$ & No & Average & Emissions factors (lb/MWh) \\
\hline $\mathrm{eGRID}^{31}$ & $\begin{array}{l}\text { Simple Emissions } \\
\text { Factors }\end{array}$ & $\begin{array}{l}\text { PDF Table of } \\
\text { Values }\end{array}$ & $\begin{array}{l}\text { PCA/BA, } \\
\text { subregions, } \\
\text { states, NERC \& } \\
\text { U.S. Average } \\
\end{array}$ & Historical & Yearly & No & $\begin{array}{l}\text { Average \& } \\
\text { Marginal }\end{array}$ & $\begin{array}{l}\text { Emissions factors (lbs/MWh), } \\
\text { total emissions (tons), nameplate } \\
\text { capacity (MW) \& net generation } \\
\text { (MWh) }\end{array}$ \\
\hline $\begin{array}{l}\text { Grid Mix } \\
\text { Explorer }^{32}\end{array}$ & $\begin{array}{l}\text { Simple Emissions } \\
\text { Factor }\end{array}$ & $\begin{array}{l}\text { Free download } \\
\text { Excel interface } \\
\text { (NETL) }\end{array}$ & $\begin{array}{l}\text { U.S. or user } \\
\text { defined }\end{array}$ & N/A & N/A & N/A & Both & $\begin{array}{l}\mathrm{EFs}(\mathrm{kg} / \mathrm{MWh} \text { delivered) for } 32 \\
\text { pollutants and CO2e, and resource } \\
\text { energy }(\mathrm{Mt} / \mathrm{MWh}) \text { for five fuels }\end{array}$ \\
\hline Colett et al..$^{24}$ & $\begin{array}{l}\text { Emissions Factor } \\
\text { Models with } \\
\text { Trading/Imports }\end{array}$ & Literature & $\begin{array}{l}\text { Combination } \\
\text { BA \& NERC }\end{array}$ & Historical & Yearly & Yes & Average & Carbon intensity \\
\hline $\begin{array}{l}\text { Marriot, J. \& } \\
\text { Matthews, S. }{ }^{27}\end{array}$ & $\begin{array}{l}\text { Emissions Factor } \\
\text { Models with } \\
\text { Trading/Imports }\end{array}$ & Literature & States & Historical & Yearly & Yes & Average & State consumption mixes \\
\hline $\begin{array}{l}\text { Soimakallio, S. \& } \\
\text { Saikku, L. }{ }^{28}\end{array}$ & $\begin{array}{l}\text { Emissions Factor } \\
\text { Models with } \\
\text { Trading/Imports }\end{array}$ & Literature & Countries & Historical & Yearly & Yes & Average & $\begin{array}{l}\text { Country Emissions factor (g } \\
\mathrm{CO}_{2} / \mathrm{kWh} \text { ) }\end{array}$ \\
\hline AVERT $^{30}$ & $\begin{array}{l}\text { Statistical } \\
\text { Relationship } \\
\text { Model }\end{array}$ & $\begin{array}{l}\text { Free downloadable } \\
\text { Excel interface }\end{array}$ & $\begin{array}{l}\text { U.S. covered in } \\
10 \text { regions }\end{array}$ & Historical & Hourly & No & Marginal & $\begin{array}{l}\text { Displaced generation \& } \\
\text { Emissions (annual, monthly, } \\
\text { weekly, hourly, region, state \& } \\
\text { county) }\end{array}$ \\
\hline $\begin{array}{l}\text { Siler-Evans et } \\
\mathrm{al}^{33}\end{array}$ & $\begin{array}{l}\text { Statistical } \\
\text { Relationship } \\
\text { Model }\end{array}$ & Literature & $\begin{array}{l}2010 \text { NERC } \\
\text { regions }\end{array}$ & Historical & Hourly & No & $\begin{array}{l}\text { Average \& } \\
\text { Marginal }\end{array}$ & Emissions factors $\left(\mathrm{kg} \mathrm{CO}_{2} / \mathrm{MWh}\right)$ \\
\hline Zivin et al. ${ }^{7}$ & $\begin{array}{l}\text { Statistical } \\
\text { Relationship } \\
\text { Model }\end{array}$ & Literature & $\begin{array}{l}3 \\
\text { interconnections } \\
\text { (emissions), } \\
\text { 2010 NERC } \\
\text { (consumption) }\end{array}$ & Historical & Hourly & $\begin{array}{l}\text { No (Consump) \& } \\
\text { Yes (Gen.) }\end{array}$ & $\begin{array}{l}\text { Average } \\
\text { (Consump. } \\
\& \text { Gen) \& } \\
\text { Marginal } \\
\text { (Consump. } \\
\text { ) }\end{array}$ & $\begin{array}{l}\text { Consumption-based emissions } \\
\text { factors \& generation-based } \\
\text { emissions factors (lbs/kWh) }\end{array}$ \\
\hline Holland et al. ${ }^{29}$ & $\begin{array}{l}\text { Statistical } \\
\text { Relationship } \\
\text { Model }\end{array}$ & Literature & 9 NERC regions & Historical & Hourly & No & Marginal & $\begin{array}{l}\text { Plant level emissions, regional } \\
\text { load and regional marginal } \\
\text { emissions factors }\end{array}$ \\
\hline $\begin{array}{l}\text { Holland, S.P \& } \\
\text { Mansur, E.T. }{ }^{34}\end{array}$ & $\begin{array}{l}\text { Statistical } \\
\text { Relationship } \\
\text { Model }\end{array}$ & Literature & $\begin{array}{l}2004 \text { NERC } \\
\text { regions }\end{array}$ & Historical & Hourly & Yes $^{\mathrm{a}}$ & $\begin{array}{l}\text { Average \& } \\
\text { Marginal }\end{array}$ & $\begin{array}{l}\text { Emissions (tons), demand (MWh) } \\
\& \text { across day and within day } \\
\text { emissions variation with load }\end{array}$ \\
\hline Jansen et al. ${ }^{35}$ & $\begin{array}{l}\text { Statistical } \\
\text { Relationship } \\
\text { Model }\end{array}$ & Literature & $\begin{array}{l}\text { U.S. Western } \\
\text { Interconnection }\end{array}$ & Historical & Hourly & $\begin{array}{l}\text { Only between } \\
\text { CA and western } \\
\text { grid }\end{array}$ & $\begin{array}{l}\text { Average \& } \\
\text { Marginal }\end{array}$ & $\begin{array}{l}\text { Generation by generator type, } \\
\text { generation mix, greenhouse gas } \\
\text { emissions factors }\end{array}$ \\
\hline
\end{tabular}




\begin{tabular}{|c|c|c|c|c|c|c|c|c|}
\hline $\begin{array}{l}\text { Electricity } \\
\text { Dispatch model } \\
\text { for GHG } \\
\text { Emissions in } \\
\text { California } \\
{\text { (EDGE-CA })^{6,23,44}}\end{array}$ & $\begin{array}{l}\text { Economic } \\
\text { Dispatch }\end{array}$ & Literature & $\begin{array}{l}3 \text { regions in } \\
\text { California } \mathrm{w} / 2 \\
\text { external regions }\end{array}$ & Historical & Hourly & Yes & Marginal & $\begin{array}{l}\text { Generation mix, combustion and } \\
\text { upstream greenhouse gas } \\
\text { emissions }\end{array}$ \\
\hline $\begin{array}{l}\text { Long-term } \\
\text { Electricity } \\
\text { Dispatch model } \\
\text { for GHG } \\
\text { emissions in } \\
\text { California } \\
\text { (LEDGE-CA) }^{23,44} \\
\end{array}$ & $\begin{array}{l}\text { Economic } \\
\text { Dispatch, } \\
\text { Capacity Planning }\end{array}$ & Literature & California & Future & Hourly & No & Marginal & $\begin{array}{l}\text { Generation mix, capacity, costs, } \\
\text { GHG emissions }\end{array}$ \\
\hline $\begin{array}{l}\text { The Oak Ridge } \\
\text { Competitive } \\
\text { Electricity } \\
\text { Dispatch } \\
\text { (ORCED) } \\
\text { Model }^{36,37}\end{array}$ & $\begin{array}{l}\text { Economic } \\
\text { Dispatch }\end{array}$ & $\begin{array}{l}\text { Oak Ridge National } \\
\text { Lab }\end{array}$ & $\begin{array}{l}\text { EIA Electricity } \\
\text { Market Module } \\
\text { Regions } 2007\end{array}$ & Future & Hourly & Yes & Average & $\begin{array}{l}\text { Average \& marginal prices, total } \\
\text { air emissions, average emissions } \\
\text { factors, total generation and } \\
\text { capacity factors by plant type, } \\
\text { variable \& fixed costs }\end{array}$ \\
\hline $\begin{array}{l}\text { The Integrated } \\
\text { MARKAL- } \\
\text { EFOM System } \\
(\text { TIMES) }\end{array}$ & $\begin{array}{l}\text { Economic } \\
\text { Dispatch, } \\
\text { Capacity Planning }\end{array}$ & IEA-ETSAP & User defined & Future & User defined & Yes & Average & $\begin{array}{l}\text { Amount of commodity consumed } \\
\text { or produced, quantity of } \\
\text { commodity traded, activity level } \\
\text { of technology, investment in new } \\
\text { technology, total system costs }\end{array}$ \\
\hline $\begin{array}{l}\text { Kim, J. D. \& } \\
\text { Rahimi, M. }{ }^{45}\end{array}$ & $\begin{array}{l}\text { Economic } \\
\text { Dispatch }\end{array}$ & Literature & $\begin{array}{l}\text { Los Angeles } \\
\text { Department of } \\
\text { Water \& Power }\end{array}$ & Future & Hourly & Yes & Marginal & $\begin{array}{l}\text { Generation mix, combustion and } \\
\text { upstream greenhouse gas } \\
\text { emissions }\end{array}$ \\
\hline EnergyPLAN $^{48}$ & $\begin{array}{l}\text { Economic } \\
\text { Dispatch }\end{array}$ & $\begin{array}{l}\text { Freeware } \\
\text { (www.energyplan.e } \\
\text { u) }\end{array}$ & User defined & $\begin{array}{l}\text { Current/ } \\
\text { Future }\end{array}$ & Hourly & Yes & Both & $\begin{array}{l}\text { Energy balances, annual } \\
\text { productions, fuel consumption, } \\
\text { imports/exports, total costs, } \mathrm{CO}_{2} \\
\text { emissions, etc. }\end{array}$ \\
\hline $\begin{array}{l}\text { PJM Hourly } \\
\text { Open-source } \\
\text { Reduced-form } \\
\text { Unit- } \\
\text { Commitment } \\
\text { Model } \\
\text { (PHORUM) }^{49}\end{array}$ & $\begin{array}{l}\text { Security } \\
\text { Constrained, } \\
\text { Economic } \\
\text { Dispatch }\end{array}$ & $\begin{array}{l}\text { Open-source } \\
\text { (Carnegie Mellon } \\
\text { Industry Center) }\end{array}$ & $\begin{array}{l}\text { PJM (divided } \\
\text { into } 5 \text { regions) }\end{array}$ & $\begin{array}{l}\text { Current/ } \\
\text { Future }\end{array}$ & Hourly & Yes & Both & Hourly power plant generation \\
\hline $\mathrm{SCOPE}^{50}$ & $\begin{array}{l}\text { Security } \\
\text { Constrained, } \\
\text { Economic } \\
\text { Dispatch }\end{array}$ & $\begin{array}{l}\text { For purchase } \\
\text { Nexant }\end{array}$ & User defined & $\begin{array}{l}\text { Current/ } \\
\text { Future }\end{array}$ & Hourly & Yes & $\begin{array}{l}\text { Average \& } \\
\text { Marginal }\end{array}$ & $\begin{array}{l}\text { LMP, reactive power pricing, } \\
\text { powerflow data, generation } \\
\text { statistics, etc. }\end{array}$ \\
\hline
\end{tabular}




\begin{tabular}{|c|c|c|c|c|c|c|c|c|}
\hline AURORAxmp $^{42}$ & $\begin{array}{l}\text { Security } \\
\text { Constrained, } \\
\text { Economic } \\
\text { Dispatch, } \\
\text { Capacity Planning }\end{array}$ & For purchase EPIS & Nodal based & Future & Hourly & Yes & $\begin{array}{l}\text { Average \& } \\
\text { Marginal }\end{array}$ & $\begin{array}{l}\text { Fuel prices, energy price, fuel } \\
\text { mix, emissions, transmission } \\
\text { flows, load and price forecasts, } \\
\text { corridor flows and limits, } \\
\text { generator operations, etc. }\end{array}$ \\
\hline GridView $^{43}$ & $\begin{array}{l}\text { Security } \\
\text { Constrained, } \\
\text { Economic } \\
\text { Dispatch }\end{array}$ & $\begin{array}{l}\text { For purchase } \mathrm{ABB} \\
\text { Inc. }\end{array}$ & User defined & $\begin{array}{l}\text { Current/ } \\
\text { Future }\end{array}$ & Hourly & Yes & $\begin{array}{l}\text { Average \& } \\
\text { Marginal }\end{array}$ & $\begin{array}{l}\text { LMP forecast, generator } \\
\text { performance, transmission \& } \\
\text { congestion info., transmission } \\
\text { asset utilization, etc. }\end{array}$ \\
\hline PLEXOS $^{53}$ & $\begin{array}{l}\text { Security } \\
\text { Constrained, } \\
\text { Economic } \\
\text { Dispatch, } \\
\text { Capacity Planning }\end{array}$ & $\begin{array}{l}\text { For purchase } \\
\text { Energy Exemplar }\end{array}$ & User defined & Future & Hourly & Yes & $\begin{array}{l}\text { Average \& } \\
\text { Marginal }\end{array}$ & $\begin{array}{l}\text { Generation unit statistics, NPV of } \\
\text { production and investment costs, } \\
\text { financial reports for generators, } \\
\text { etc. }\end{array}$ \\
\hline $\begin{array}{l}\text { Promod IV }{ }^{54} \\
\text { (Can be } \\
\text { integrated with } \\
\text { Strategist })^{55}\end{array}$ & $\begin{array}{l}\text { Security } \\
\text { Constrained, } \\
\text { Economic } \\
\text { Dispatch }\end{array}$ & $\begin{array}{l}\text { For purchase } \mathrm{ABB} \\
\text { Inc. }\end{array}$ & User defined & $\begin{array}{l}\text { Current/ } \\
\text { Future }\end{array}$ & Hourly & Yes & $\begin{array}{l}\text { Average \& } \\
\text { Marginal }\end{array}$ & $\begin{array}{l}\text { LMP for buses, total cost by } \\
\text { region size, generating unit } \\
\text { revenues, costs \& operating } \\
\text { statistics (emissions, CF, output, } \\
\text { etc.) }\end{array}$ \\
\hline MAPs $^{56}$ & $\begin{array}{l}\text { Security } \\
\text { Constrained, } \\
\text { Economic } \\
\text { Dispatch } \\
\end{array}$ & For purchase GE & User defined & $\begin{array}{l}\text { Current/ } \\
\text { Future }\end{array}$ & Hourly & Yes & $\begin{array}{l}\text { Average \& } \\
\text { Marginal }\end{array}$ & $\begin{array}{l}\text { Plant level generation \& } \\
\text { emissions, production costs, spot } \\
\text { price, revenue value, consumer } \\
\text { payments, etc. }\end{array}$ \\
\hline GTMax $^{57-59}$ & $\begin{array}{l}\text { Economic } \\
\text { Dispatch }\end{array}$ & $\begin{array}{l}\text { For purchase } \\
\text { ADICA }\end{array}$ & User defined & Future & Hourly & Yes & $\begin{array}{l}\text { Average \& } \\
\text { Marginal }\end{array}$ & $\begin{array}{l}\text { Financial reports (market } \\
\text { transactions, market clearing } \\
\text { prices, revenue \& expenses, } \\
\text { marginal costs, etc.), transmission } \\
\text { constraints, plant level generation, } \\
\text { non-power releases \& reservoir } \\
\text { operations }\end{array}$ \\
\hline $\operatorname{ReEDS}^{40-43}$ & $\begin{array}{l}\text { Economic } \\
\text { Dispatch, } \\
\text { Capacity Planning }\end{array}$ & $\begin{array}{l}\text { Created by NREL } \\
\text { for research } \\
\text { purposes }\end{array}$ & $\begin{array}{l}356 \text { resource } \\
\text { regions grouped } \\
\text { into } 4 \text { levels of } \\
\text { larger regions }\end{array}$ & Future & $\begin{array}{l}\text { Bi-yearly } \\
17 \text { annual }^{\mathrm{b}} \\
\text { time slices }^{\mathrm{c}}\end{array}$ & Yes & Average & $\begin{array}{l}\text { Generation capacity, generation } \\
\text { mix, storage capacity, } \\
\text { transmission capacity expansion, } \\
\text { electric sector costs, electricity } \\
\text { price, fuel prices and } \mathrm{CO}_{2} \\
\text { emissions, etc. }\end{array}$ \\
\hline
\end{tabular}




\begin{tabular}{|c|c|c|c|c|c|c|c|c|}
\hline $\mathrm{IPM}^{60}$ & $\begin{array}{l}\text { Economic } \\
\text { Dispatch, } \\
\text { Capacity Planning }\end{array}$ & $\begin{array}{l}\text { Created by EPA for } \\
\text { research purposes }\end{array}$ & $\begin{array}{l}64 \text { regions } \\
\text { (covers all U.S. } \\
\text { states \& D.C.) } \\
11 \text { Canadian } \\
\text { regions }\end{array}$ & Future & Hourly & Yes & $\begin{array}{l}\text { Average \& } \\
\text { Marginal }\end{array}$ & $\begin{array}{l}\text { Generation, Capacity mix, } \\
\text { Capacity additions and } \\
\text { retirements, Capacity and energy } \\
\text { prices, Power production costs, } \\
\text { Fuel consumption, Fuel supply } \\
\text { and demand, Fuel prices for coal, } \\
\text { natural gas and biomass, } \\
\text { emissions, emissions allowance } \\
\text { price, etc. }\end{array}$ \\
\hline $\begin{array}{l}\text { Strategist }{ }^{55} \text { (can } \\
\text { be integrated } \\
\text { with Promod IV) }\end{array}$ & $\begin{array}{l}\text { Economic } \\
\text { Dispatch, } \\
\text { Capacity Planning }\end{array}$ & $\begin{array}{l}\text { For purchase } \mathrm{ABB} \\
\text { Inc. (comprised of } \\
\text { multiple modules) }\end{array}$ & User defined & Future & $\begin{array}{l}\text { Seasonal or } \\
\text { Annual }\end{array}$ & Yes & $\begin{array}{l}\text { Average \& } \\
\text { Marginal }\end{array}$ & $\begin{array}{l}\text { Outputs are extensive and vary by } \\
\text { module (Generating unit statistics, } \\
\text { load forecasts, resource cost, } \\
\text { revenue requirements, fuel data, } \\
\text { system emissions etc.) }\end{array}$ \\
\hline $\operatorname{NESSIE}^{10,46,47}$ & $\begin{array}{l}\text { Economic } \\
\text { Dispatch, } \\
\text { Capacity Planning }\end{array}$ & $\begin{array}{l}\text { Output data for } \\
\text { purchase EPRI }\end{array}$ & $\begin{array}{l}\text { EIA Electricity } \\
\text { Market Module } \\
\text { Regions } 2007\end{array}$ & Future & $\begin{array}{l}6 \text { Typical } \\
\text { days per } \\
\text { year in } 2 \\
\text { hour blocks }\end{array}$ & No & Marginal & $\begin{array}{l}\text { Emissions (tons), emissions } \\
\text { intensity (tons/MWh), prices, } \\
\text { profits, loads served by } \\
\text { technologies, electricity costs, etc. }\end{array}$ \\
\hline
\end{tabular}

a) Temperature variables control for imports and exports

b) Model output time scale

c) Model analysis time scale 